\title{
Water quality, discharge and catchment attributes for large-sample studies in Germany - QUADICA
}

Pia Ebeling ${ }^{1}$, Rohini Kumar², Stefanie R. Lutz ${ }^{1,3}$, Tam Nguyen ${ }^{1}$, Fanny Sarrazin², Michael Weber², Olaf Büttner $^{4}$, Sabine Attinger ${ }^{2}$, Andreas Musolff ${ }^{1}$

$5{ }^{1}$ Department of Hydrogeology, Helmholtz Centre for Environmental Research-UFZ, Leipzig, 04318, Germany

${ }^{2}$ Department of Computational Hydrosystems, Helmholtz Centre for Environmental Research-UFZ, Leipzig, 04318, Germany

${ }^{3}$ Copernicus Institute of Sustainable Development, Utrecht, 3584 CB, the Netherlands

$10{ }^{4}$ Department Aquatic Ecosystems Analysis and Management, Helmholtz Centre for Environmental Research-UFZ, Magdeburg, 39114, Germany

Correspondence to: Pia Ebeling (pia.ebeling@ufz.de)

Abstract. Environmental data are the key to define and address water quality and quantity challenges at catchment scale. Here, we present the first large-sample water quality data set for 1386 German

15 catchments covering a large range of hydroclimatic, topographic, geologic, land use and anthropogenic settings. QUADICA (water QUAlity, DIscharge and Catchment Attributes for large-sample studies in Germany) combines water quality with water quantity data, meteorological and nutrient forcing data, and catchment attributes. The data set comprises time series of riverine macronutrient concentrations (species of nitrogen, phosphorus and organic carbon) and diffuse nitrogen forcing data at catchment scale (nitrogen

20 surplus, atmospheric deposition and fixation). Time series are generally aggregated to an annual basis; however, for 140 stations with long-term water quality and quantity data (more than 20 years), we additionally present monthly median discharge and nutrient concentrations, flow-normalized concentrations and corresponding mean fluxes as outputs from weighted regressions on time, discharge, and season (WRTDS). The catchment attributes include catchment nutrient inputs from point and diffuse sources and characteristics from topography, climate, land cover, lithology and soils. This comprehensive, freely available data collection can facilitate large-sample data-driven water quality assessments at catchment scale as well as mechanistic modeling studies. 


\section{Introduction}

Understanding hydrological and biogeochemical processes at various spatiotemporal scales is a major goal in catchment hydrology and is particularly relevant for robust predictions of water quantity and quality and adequate catchment management. Analyzing observations of spatial and temporal dynamics of water quantity and quality at the catchment scale can give insights into relevant processes using a “pattern to process” approach (Sivapalan, 2006). Especially large-sample studies covering a wide range of catchments can advance our knowledge on patterns across scales, catchment similarity, and dominant processes, beyond a single catchment or local behavior (Addor et al., 2020; Kingston et al., 2020). Such studies allow for generalizable theories and applications by "balancing depth with breadth" and facilitate classifications, regionalization and a better understanding of uncertainty in model predictions (Gupta et

40 al., 2014). In this context, machine learning techniques have proven promising tools to recognize patterns and their relationships to predictors and are increasingly applied (Schmidt et al., 2020; Shen, 2018). Thus, environmental data are the key for process understanding and hypothesis testing (Li et al., 2021). Although data collection and availability is steadily increasing, partly due to automated and remote sensing techniques, harmonized and quality controlled large-sample water quality and quantity data are

45 still not widely available, which slows down progress in our understanding of the complex coupled hydrological and biogeochemical systems across larger scales and samples (Li et al., 2021).

In recent years, the application of large-sample studies has been advancing fast for (surface) water quantity studies investigating dominant processes and drivers of water flow characteristics. Gupta et al. (2014) provided an overview of such studies, with the first ones published in the 1990s. They were

50 followed by a recent surge in studies documenting and analyzing large-sample hydrologic data sets such as Newman et al. (2015), Kuentz et al. (2017), Do et al. (2017), Gnann et al. (2020), Tarasova et al. (2020), Merz et al. (2020). These studies identified catchment typologies, archetypal behavior and underlying controls e.g. regarding discharge variability across Europe (Kuentz et al., 2017), catchments with similar runoff event types (Tarasova et al., 2020) or how catchment discharge attenuates and shifts

55 climate seasonality (Gnann et al., 2020).

In contrast, large-sample studies for water quality are less common. Nevertheless, some recent largesample water quality studies have shown to increase our understanding of catchment functioning in terms 
of mobilization, transport, and environmental fate of solutes and particulates and the generality of these functions. For example, Monteith et al. (2007) linked widespread positive trends in DOC concentrations observed in Europe and North America to decreasing atmospheric sulphur and chloride depositions. Godsey et al. (2009) and Godsey et al. (2019) provided wide evidence that weathering derived solutes are mostly exported chemostatically with low concentration variance. Basu et al. (2010) derived the hypothesis of chemostatic nutrient export resulting from homogenized sources due to the legacy of high inputs. More recently, Zarnetske et al. (2018) and Ebeling et al. (2021c) both provided evidence of widespread transport-limited DOC export from small to large catchments. However, several questions of general patterns, catchment similarities and typologies and their underlying controls remain open, for example, concerning the extent and recovery of nutrient legacy for both nitrogen $(\mathrm{N})$ and phosphorous (P) (Chen et al., 2018), the extent of macronutrient interactions in differing landscape and anthropogenic settings and throughout the river network (Wollheim et al., 2018), and the impact of climate change on

70 water quality trajectories in various catchments (Kaushal et al., 2018).

At the moment, large-sample studies are still hampered by limited availability (number of stations, number of samples, and covered regions) and accessibility of spatially and temporally harmonized largesample data collections (e.g., Addor et al., 2020), despite recent efforts to make consistent large-sample data sets of catchment hydrology for both water quantity and water quality in streams publicly available

75 (e.g., Virro et al., 2021). Prominent examples for large-sample hydrological data sets including catchment attributes are the Catchment Attributes and MEteorology for Large-sample Studies (CAMELS) data sets, available for the USA (Addor et al., 2017), Chile (Alvarez-Garreton et al., 2018), Brazil (Chagas et al., 2020), Great Britain (Coxon et al., 2020), and Australia (Fowler et al., 2021). More recently, the multinational LArge-SaMple DAta for Hydrology and Environmental Sciences (LamaH, Klingler et al., 2021)

80 have provided hydrometeorological time series at an hourly resolution together with catchment attributes. For stream water quality, currently available large-sample data sets focus on water quality time series only but lack additional data. Recently, two global databases of surface water quality were published, which combine data of several existing databases in homogenized and quality checked form: the Surface Water Chemistry database (SWatCh; Rotteveel and Sterling, 2021) with a focus on variables relevant for 85 acidification and the Global River Water Quality Archive (GRQA; Virro et al., 2021) with a focus on 
macronutrients. Both include the global databases Global Freshwater Quality Database (GEMStat; UNEP, 2018), GLObal RIver CHemistry database (GLORICH; Hartmann et al., 2014) and the European WaterBase (EEA, 2020), although spatiotemporal coverage of the data varies strongly. These are important recent advances towards open science in water quality research. However, to the authors'

90 knowledge, there is currently no combined, ready-to-use data set of metrics of water quality, quantity, catchment attributes and forcing data (such as meteorological and nutrient inputs), which would allow investigating water quality dynamics and their controls. Moreover, large-sample and cross-regional studies are especially challenging in countries like Germany, where data responsibility is scattered between federal states, and where data are often not freely available nor homogenized between water

95 quantity and quality stations. Nevertheless, there have been a few Germany-wide water quality studies on groundwater (Knoll et al., 2020) and surface water (Ebeling et al., 2021c) recently.

The key objective here is to provide a spatially and temporally consistent, comprehensive data set of joint water quality and quantity data, catchment attributes and nutrient inputs for German catchments, which is ready-to-use and freely available supporting an open science philosophy and FAIR data principles. In 100 this "Water QUAlity, DIscharge and Catchment Attributes for large-sample studies in Germany" (QUADICA) data set, we have complemented available data sets of catchment attributes with new data on water quality and water quantity. These data include delineated catchment boundaries, catchment responses in terms of macronutrient concentrations (species of $\mathrm{N}, \mathrm{P}$ and organic carbon (OC)) and discharge (Q), forcing data in terms of meteorological and diffuse nitrogen inputs and average catchment 105 attributes. We distinguish stations with a high data availability, which allows further estimation of daily concentrations and fluxes using a regression approach, and stations with lower availability, for which aggregated observed concentrations are reported. For water quality (Section 3.1) and water quantity (Section 3.2), we provide

(1) time series of annual medians of observed macronutrient concentrations (dissolved and total forms of 110 N, P and OC) and of observed discharge,

(2) time series of monthly and annual medians of estimated daily macronutrient concentrations and flownormalized concentrations as well as mean nutrient fluxes and medians of observed discharge for stations with high data availability, 
(3) monthly medians of observed concentrations and discharge over the whole time series.

115 Additionally, we provide time series of driving forces (Section 3.3 and 3.4) and catchment attributes (Section 4):

(4) time series of observed monthly meteorological forcing variables as catchment averages (Section 3.3),

(5) time series of estimated annual net diffuse nitrogen inputs to the catchments (Section 3.4),

(6) average catchment characteristics, i.e. topography, land cover, nutrient sources, lithology and soils, 120 and hydroclimate (Section 4).

We envision that the QUADICA data set will directly enable large-sample assessments of mean concentrations and fluxes, and concentration and flux variability in terms of long-term trends, seasonality and relationships to discharge as well as their relationships to catchment attributes. We believe that the data set will allow better understanding of catchment functioning and water management beyond regional

125 scales and stimulate provisioning and analysis of further water quality data at national to continental scales.

\section{Catchment selection and delineation}

The station selection and catchment delineation have been presented in a previous study (Ebeling et al., 2021c) and data repository (Ebeling, 2021) and are now included in the new QUADICA data set. All data

130 sets use the same unique identifier (OBJECTID) for the stations and corresponding catchments. The station selection is based on riverine water quality data assembled from the German federal state environmental authorities, who are responsible for the routine monitoring of water quality in Germany (Musolff et al., 2020; Musolff, 2020) and take grab samples at approximately monthly intervals. For this data set, 1386 water quality stations were selected and catchment boundaries delineated (Fig. 1). These

135 stations meet the following quality criteria concerning water quality and catchment delineation:

1. Water quality data cover at least three years, include a minimum of 70 samples from 2000 to 2015 after outlier removal, and cover all seasons, i.e. seasonal coverage of at least $10 \%$ of the samples in each quarter considering all possible combinations of three consecutive months 
(criteria one to three as described in Ebeling et al., 2021c). These criteria should ensure that a representative amount of data is available. Stations fulfilling these water quality data criteria for $\mathrm{NO}_{3}-\mathrm{N}$ or $\mathrm{PO}_{4}-\mathrm{P}$ were preselected (i.e., 1692 stations). Other variables (e.g. TP, TN, DOC) were not used in this initial step of station selection.

2. In a second step, we delineated the catchment area from topography for these preselected stations and verified them as described here. The topographic catchment boundaries were delineated based on a 100 m flow accumulation grid derived from a digital elevation model (DEM; resampled from $25 \mathrm{~m}$ to $100 \mathrm{~m}$ using the average; EEA, 2013) using spatial analysis tools and D8 flow direction type. The river network from the Rivers and Catchments of Europe - Catchment Characterisation Model (De Jager and Vogt, 2007) was used to burn by 10 m into the DEM before deriving the flow accumulation. The stations were snapped or manually moved towards the representative flow accumulation stream to define the catchment outlets (pour points). The resulting topography-based catchment polygons were quality-controlled manually by a comparison to the real river network. In case of major deviations, a few manual adaptations of the burned river segments were done if they substantially improved the overlap without hindering neighboring catchment delineations. In case of insufficient spatial overlap that could not be improved, stations were discarded from the selection. This resulted in a final set of 1386 catchments.

160 The varying density of stations across Germany (Fig. 1a) has two main reasons: firstly, the provision of raw data varied in number of stations, number of samples per compound and station, and time series length among the federal states; secondly, the topographic delineation of catchment boundaries was more successful where the topography is more pronounced, giving less delineable catchments in northern Germany. The delineated catchment boundaries are provided with the data set and enable the user to 165 develop further geoinformation routines, e.g. to extract characteristics from other geographic data sets. 


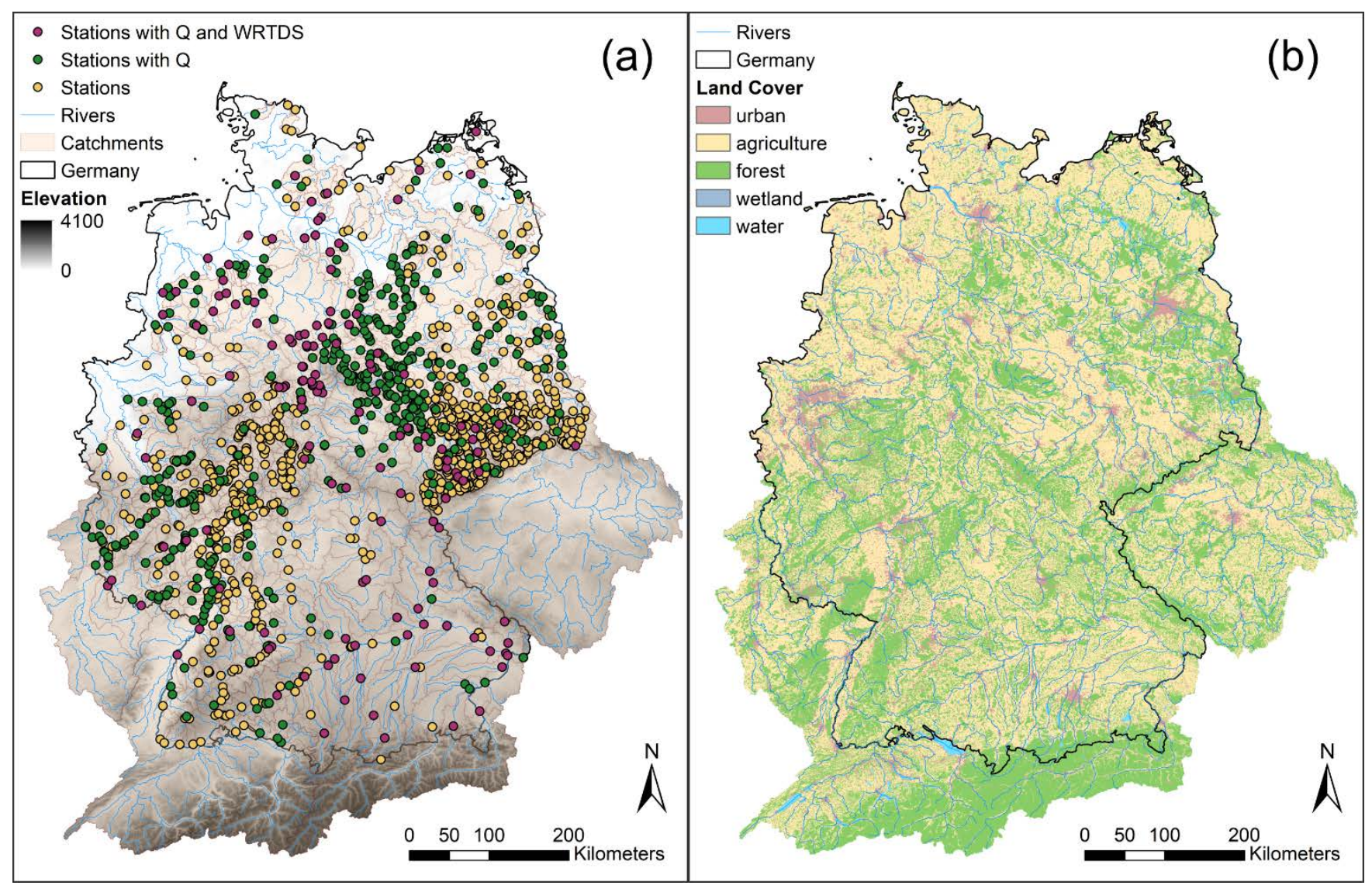

Figure 1: Map of (a) water quality stations, catchments and elevation (EEA, 2013) and (b) map of land cover (EEA, 2016b). Colors in (a) distinguish between stations with (green) and without discharge (Q) data (yellow) and long-term C-Q stations (dark purple) with high data availability (also WRTDS stations; for details see Section 3.1). WRTDS - Weighted Regression on Time, Discharge and Season.

\section{Time series}

For the 1386 delineated catchments, riverine concentration time series of nitrate $\left(\mathrm{NO}_{3}-\mathrm{N}\right)$, mineral nitrogen $\left(\mathrm{N}_{\min }\right)$, total nitrogen $(\mathrm{TN})$, phosphate $\left(\mathrm{PO}_{4}-\mathrm{P}\right)$, total phosphorus (TP), dissolved organic carbon (DOC), and total organic carbon (TOC) are provided (Table 1). They are supplemented by time series of

175 discharge (where available) and forcing variables (meteorological drivers and diffuse $\mathrm{N}$ input). Due to limited data availability, not all variables can be provided for all stations. 
Table 1: Provided time series data, their basis (observed or estimated), aggregation type, temporal resolution and source of original data, which was used to calculate the aggregated data provided here. WRTDS -Weighted Regression on Time, Discharge and Season.

\begin{tabular}{|c|c|c|c|c|c|}
\hline Variable & Section & Data basis & $\begin{array}{l}\text { Temporal (Spatial) } \\
\text { Aggregation }\end{array}$ & $\begin{array}{l}\text { Temporal } \\
\text { resolution }\end{array}$ & Source \\
\hline \multirow{3}{*}{$\begin{array}{l}\text { Concentration of } \\
\mathrm{NO}_{3}-\mathrm{N}, \mathrm{N}_{\min }, \mathrm{TN}, \\
\mathrm{PO}_{4}-\mathrm{P}, \mathrm{TP}, \mathrm{DOC}, \\
\mathrm{TOC}\end{array}$} & \multirow[t]{3}{*}{3.1} & observed & median & annual & $\begin{array}{l}\text { Musolff et al. (2020); Musolff } \\
\text { (2020) }\end{array}$ \\
\hline & & $\begin{array}{l}\text { daily estimated } \\
\text { using WRTDS }\end{array}$ & median & monthly & $\begin{array}{l}\text { Musolff et al. (2020); Musolff } \\
\text { (2020) }\end{array}$ \\
\hline & & observed & long-term median & monthly & $\begin{array}{l}\text { Musolff et al. (2020); Musolff } \\
\text { (2020) }\end{array}$ \\
\hline \multirow[t]{3}{*}{ Discharge } & \multirow[t]{3}{*}{3.2} & observed & median & annual & $\begin{array}{l}\text { Musolff et al. (2020); Musolff } \\
\text { (2020) }\end{array}$ \\
\hline & & observed & median & monthly & $\begin{array}{l}\text { Musolff et al. (2020); Musolff } \\
\text { (2020) }\end{array}$ \\
\hline & & observed & long-term median & monthly & $\begin{array}{l}\text { Musolff et al. (2020); Musolff } \\
\text { (2020) }\end{array}$ \\
\hline Precipitation & 3.3 & $\begin{array}{l}\text { observed } \\
\text { gridded }\end{array}$ & sum (average) & monthly & $\begin{array}{l}\text { E-OBS, v18.0e; Cornes et al. } \\
\text { (2018) }\end{array}$ \\
\hline $\begin{array}{l}\text { Potential } \\
\text { evapotranspiration }\end{array}$ & 3.3 & estimated & sum (average) & monthly & $\begin{array}{l}\text { E-OBS, v18.0e; Cornes et al. } \\
\text { (2018) }\end{array}$ \\
\hline $\begin{array}{l}\text { Mean air } \\
\text { temperature }\end{array}$ & 3.3 & $\begin{array}{l}\text { observed } \\
\text { gridded }\end{array}$ & average (average) & monthly & $\begin{array}{l}\text { E-OBS, v18.0e; Cornes et al. } \\
\text { (2018) }\end{array}$ \\
\hline $\begin{array}{l}\text { Diffuse } \mathrm{N} \text { input as } \\
\text { total }\end{array}$ & 3.4 & estimated & (average) & annual & see Section 3.4 \\
\hline $\begin{array}{l}\text { Diffuse } \mathrm{N} \text { input } \\
\text { from } \\
\text { areas }\end{array}$ & 3.4 & estimated & (average) & annual & see Section 3.4 \\
\hline
\end{tabular}

\subsection{Water quality time series}

\subsubsection{Annual median concentrations}

Annual medians of concentration data are presented for time series of the 1386 stations fulfilling the water quality criteria, analogously to the catchment selection criteria described in Section 2. The following steps 
were applied for each station and solute separately: we removed values of zero and used an outlier test

185 for each time series, removing values above mean concentration $+4 *$ standard deviation in logarithmic space (confidence level $>99.99 \%$ for log normally distributed data). To calculate summary statistics, we substituted concentration values below the detection limit (left-censored data) with half the detection limit.

The resulting data density distributions over time and the number of years covered by each variable show 190 the highest data availability for TOC, $\mathrm{PO}_{4}-\mathrm{P}$ and $\mathrm{NO}_{3}-\mathrm{N}$ in more recent years (Fig. 2). An overview of the time-series statistics for each variable is given in Table 2, while time series are shown in Appendix A Fig. A1. For $\mathrm{NO}_{3}-\mathrm{N}$ concentrations, the number of stations with available data is 1339 and the median number of samples per station is 157 . The earliest time series starts in 1954, while the median start across stations is in 1994. The median time series length is 19 years and the maximum time series length is 61 195 years. For $\mathrm{PO}_{4}-\mathrm{P}$ concentrations, the number of stations with available data is 1330 and the median number of samples per station is 152 . The earliest time series starts in 1965, while the median start across stations is in 1993. The median time series length is 20 years and the maximum time series length is 48 years. For TOC concentrations, the number of stations with available data is 1296 and the median number of samples per station is 139 . The earliest time series starts in 1979, while the median start across stations 200 is in 1999. The median time series length is 15 years and the maximum time series length is 36 years. For all water quality variables, the median of the first year of the time series is in the 1990s and the median number of samples per station and year is 12 , indicating that grab samples were on average taken on a monthly basis. 


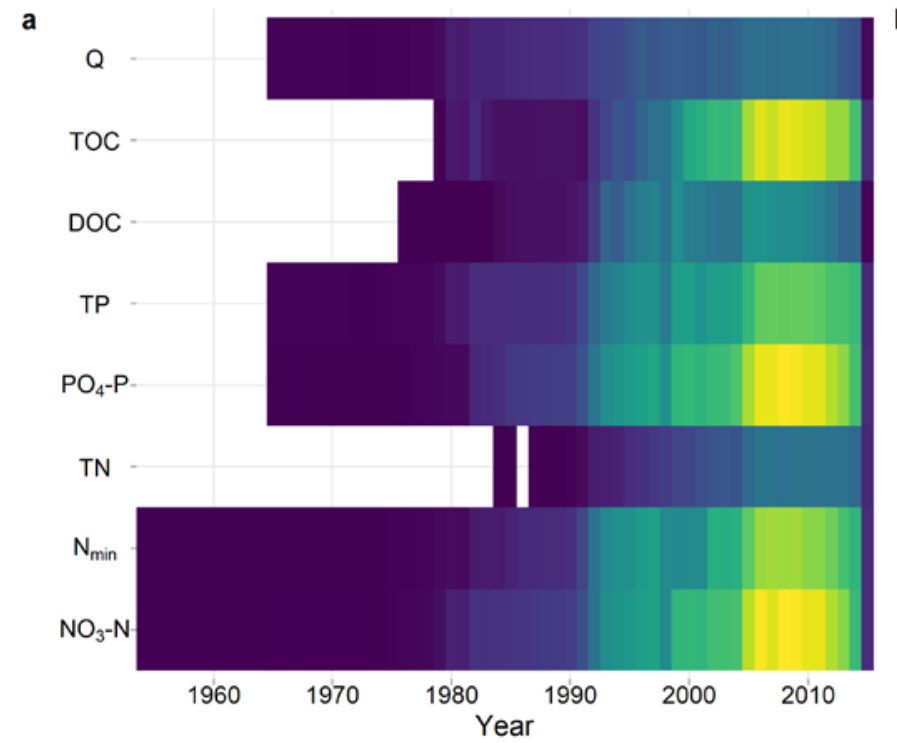

Stations

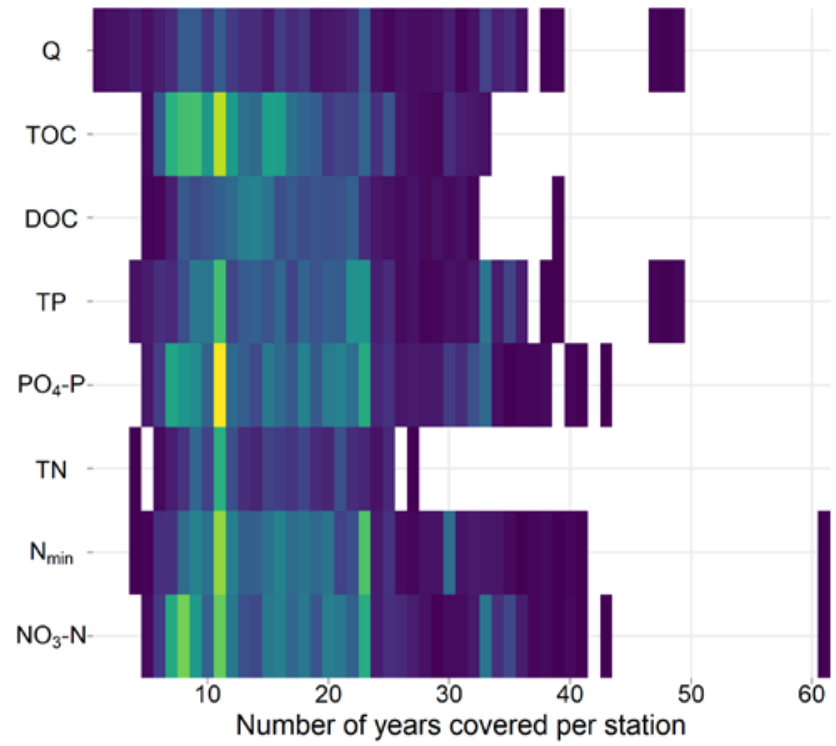

Stations

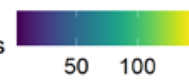

205 Figure 2: Heat map of (a) the number of stations with available annual medians over time and per variable and (b) the number of years covered by each station. In (a) discharge $Q$ refers to the median $Q$ from grab sample dates. For visualization purposes values from 1954 are shown, omitting one sample reported for 1900.

Table 2: Number of stations with available data for the water quality compounds and discharge during grab sampling dates, earliest and median start year of time series, maximum and median time series length and covered years (i.e. years with available data), median number of samples per stations and per station and year, and number of outliers removed. * omitting one sample from 1900.

\begin{tabular}{|c|c|c|c|c|c|c|c|c|}
\hline $\begin{array}{l}\text { Variable } \\
\text { Unit }\end{array}$ & $\begin{array}{c}\mathbf{Q} \\
\mathbf{m}^{3} \mathbf{s}^{-1}\end{array}$ & $\begin{array}{c}\mathrm{NO}_{3}-\mathrm{N} \\
\mathrm{mg} \mathrm{l}^{-1}\end{array}$ & $\begin{array}{c}\mathrm{N}_{\min } \\
\mathrm{mg} \mathrm{l}^{-1}\end{array}$ & $\begin{array}{c}\text { TN } \\
\text { mg l}^{-1}\end{array}$ & $\begin{array}{l}\mathrm{PO}_{4}-\mathrm{P} \\
\mathrm{mg} \mathrm{l}^{-1}\end{array}$ & $\begin{array}{c}\text { TP } \\
\text { mg l}^{-1}\end{array}$ & $\begin{array}{l}\text { DOC } \\
\mathrm{mg} \mathrm{l}^{-1}\end{array}$ & $\begin{array}{c}\text { TOC } \\
\text { mg l}^{-1}\end{array}$ \\
\hline Number of stations & 581 & 1339 & 1149 & 514 & 1330 & 1046 & 744 & 1296 \\
\hline Earliest start & $1965 *$ & $1954^{*}$ & 1954 & 1984 & 1965 & $1965 *$ & 1976 & 1979 \\
\hline Median start year & 1993 & 1994 & 1993 & 1999 & 1994 & 1993 & 1993 & 1999 \\
\hline $\begin{array}{l}\text { Median time series } \\
\text { length per station } \\
\text { (years covered) }\end{array}$ & $\begin{array}{l}19 \\
(16)\end{array}$ & $\begin{array}{l}19 \\
(16)\end{array}$ & $\begin{array}{l}21 \\
(16)\end{array}$ & $\begin{array}{l}15 \\
(13)\end{array}$ & $\begin{array}{l}20 \\
(16)\end{array}$ & $\begin{array}{l}21 \\
(17)\end{array}$ & $\begin{array}{c}20 \\
(15)\end{array}$ & $\begin{array}{c}15 \\
(13)\end{array}$ \\
\hline $\begin{array}{l}\text { Maximum time series } \\
\text { length per station } \\
\text { (years covered) }\end{array}$ & $\begin{array}{l}49 * \\
(49)\end{array}$ & $\begin{array}{l}61 * \\
(61)\end{array}$ & $\begin{array}{c}61 \\
(61)\end{array}$ & $\begin{array}{l}31 \\
(27)\end{array}$ & $\begin{array}{l}48 \\
(43)\end{array}$ & $\begin{array}{l}49 * \\
(49)\end{array}$ & $\begin{array}{c}39 \\
(39)\end{array}$ & $\begin{array}{l}36 \\
(33)\end{array}$ \\
\hline
\end{tabular}




\begin{tabular}{|l|c|cccccccc|}
\hline $\begin{array}{l}\text { Total number of } \\
\text { samples }\end{array}$ & 156,388 & 309,965 & 235,015 & 92,876 & 297,591 & 258,059 & 139,440 & 239,282 \\
$\begin{array}{l}\text { Median number of } \\
\text { samples per station }\end{array}$ & 170 & 157 & 153 & 149 & 152 & 165 & 164 & 139 \\
$\begin{array}{l}\text { Median number of } \\
\text { samples per station and }\end{array}$ & 13 & 12 & 12 & 12 & 12 & 12 & 12 & 12 \\
year & & & & & & & & & \\
Number of outliers & - & 59 & 52 & 45 & 68 & 326 & 257 & 795 \\
Maximum fraction of & - & 1.7 & 1.7 & 1.7 & 1.7 & 2.5 & 3.1 & 3.6 \\
outliers per station [\%] & & & & & & & & \\
\hline
\end{tabular}

\subsubsection{Monthly median concentrations and mean fluxes for stations with high data availability}

For stations with high data availability, a Weighted Regression on Time, Discharge and Season (WRTDS;

215 Hirsch et al., 2010) was applied using the R package EGRET (version 3.0.2; Hirsch and De Cicco, 2015). We refer to these stations as 'WRTDS stations' for short. WRTDS represents long-term trends, seasonal components and discharge-related variability of the water quality variables (Hirsch et al., 2010). The criteria, checked for each station and compound separately, were a time series of at least 20 years, at least 150 samples of water quality, no data gaps larger than $20 \%$ of the total time series length and a complete

220 time series of daily discharge. The number of WRTDS stations varies between 44 for TN and 126 for $\mathrm{PO}_{4}-\mathrm{P}$ (Table 3), while the fraction of stations with high data availability varies between $4.9 \%$ for TOC and $11.7 \%$ for TP.

For WRTDS stations, we provide monthly and annual median estimated water quality and observed quantity data in addition to the annual observed data (see above). More specifically, we provide monthly and annual median concentration and flow-normalized concentration and mean flux estimates from the WRTDS model output and median observed discharge (see Section 3.2) if data are available for at least $80 \%$ of the respective time frame. The median $\mathrm{R}^{2}$ between WRTDS-modelled and observed concentrations varies between 0.44 for DOC and TOC and 0.75 for TN (Table 3), while overall $69.3 \%$ 
of the catchment and compound combinations have a median $\mathrm{R}^{2}$ of at least 0.5 . The median bias varies between $-1.4 \%$ for $\mathrm{PO}_{4}-\mathrm{P}$ (negative values indicate overestimation) and $0.2 \%$ for $\mathrm{NO}_{3}-\mathrm{N}$ (positive values indicate underestimation). Overall, $51 \%$ of the catchments have a bias below $1 \%$ and $95 \%$ below $5 \%$ respectively. An overview of the availability of WRTDS stations and model performances is given in Table 3 and shown in Fig. A2, while their locations are shown in Fig. 1a and performances provided in the data repository.

Table 3: Number of stations with high data availability (WRTDS stations) for each compound and median coefficient of determination of WRTDS models.

\begin{tabular}{|c|c|c|c|c|c|c|c|c|}
\hline $\begin{array}{l}\text { Variable } \\
\text { Unit }\end{array}$ & total & $\begin{array}{l}\mathrm{NO}_{3}-\mathrm{N} \\
\mathrm{mg} \mathrm{l}^{-1}\end{array}$ & $\begin{array}{l}\mathrm{N}_{\min } \\
\mathrm{mg} \mathrm{l}^{-1}\end{array}$ & $\begin{array}{c}\mathrm{TN} \\
\mathrm{mg} \mathrm{l}^{-1}\end{array}$ & $\begin{array}{l}\mathrm{PO}_{4-\mathrm{P}} \\
\mathrm{mg} \mathrm{l}^{-1}\end{array}$ & $\begin{array}{c}\text { TP } \\
\mathrm{mg} \mathrm{l}^{-1}\end{array}$ & $\begin{array}{l}\text { DOC } \\
\text { mg l-1 }^{-1}\end{array}$ & $\begin{array}{l}\text { TOC } \\
\text { mg l}^{-1}\end{array}$ \\
\hline $\begin{array}{l}\text { Number of } \\
\text { WRTDS stations }\end{array}$ & 140 & 125 & 97 & 44 & 126 & 122 & 61 & 64 \\
\hline Median $\mathbf{R}^{2}$ & 0.61 & 0.63 & 0.71 & 0.75 & 0.69 & 0.53 & 0.44 & 0.44 \\
\hline Median bias [\%] & -0.3 & 0.2 & 0.1 & 0.1 & -1.4 & -0.9 & -0.6 & -0.6 \\
\hline
\end{tabular}

\subsubsection{Monthly median concentrations over the time series}

240 Next to annual and monthly time series, we provide long-term monthly medians over the complete time series of each station, enabling assessments of average seasonal variability. The provided data frame in QUADICA indicates the number of samples available for the corresponding month across the years, based on which representativeness can be assessed and quality criteria can be defined.

\subsection{Water quantity time series}

245 For about $43 \%$ of the water quality stations $(n=590)$, information on discharge is available (Fig. 1a) and provided harmonized with the water quality data (i.e. annual and monthly resolution). The discharge information is a collection of data provided by the federal states together with the concentration data either as daily discharge time series or for the times of grab sampling of water quality. Additionally, we integrated daily discharge data from 53 stations available from the Global Runoff Data Center (GRDC) 
250 to increase the number of stations with available discharge time series. We matched GRDC gauging stations to the existing water quality stations using the "proximity/point distance" tool in ArcGIS with a search radius of $500 \mathrm{~m}$. For each match, we checked the consistency of river names and visually the locations. The corresponding GRDC station numbers are indicated in the metadata of the water quality and quantity data set (Musolff, 2020). For the original daily discharge data, the reader may refer to the regularly published and accessible data at the GRDC portal (https://portal.grdc.bafg.de).

\subsubsection{Annual median discharge}

Annual median discharge is aggregated from available observed discharge data. For 324 water quality stations, a co-located Q station with a continuous daily Q record is available. However, the time series may include data gaps and for nine of the co-located discharge stations, the time series of discharge and concentration data do not overlap at all. For additional 266 stations, Q data was only available at the time that the grab samples were taken. This resulted in a set of 581 stations for which Q data are available on the sampling dates of concentration data. We extracted annual median discharge both from continuous daily data and from dates when the water quality sample was taken (median of 12 values per year, Table 2) for the water quality stations. The data density distribution of annual discharge over time is shown in

265 Fig. 3a. Similar to the concentration data, the data availability is higher in more recent years, with the maximum of 449 stations in 2010. The number of years covered is, however, higher compared to water quality data for several stations (Fig. 3b). For stations with available daily discharge data, both annual median values of the daily data and the data from grab sample days were compared (Fig. 3c). This shows that annual median values from grab sample dates do not contain an overall bias, but scatter around the 1:1 line, so that they can be considered as relatively robust estimates of annual median discharge. Time series are shown in Appendix A Fig. A3. The data set provides additionally provide the number of samples used to calculate the medians as a measure of robustness. 
(a)

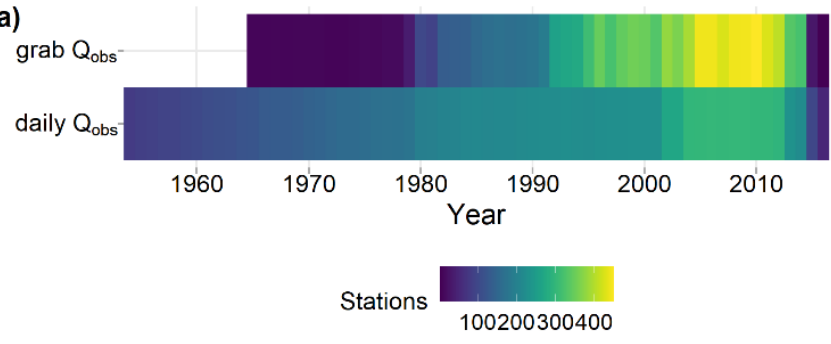

(b)

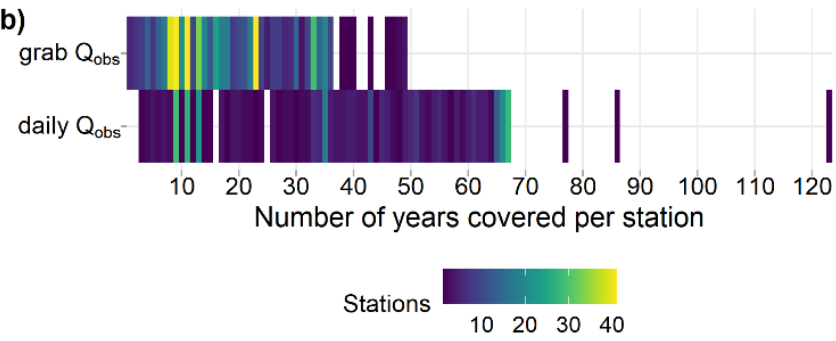

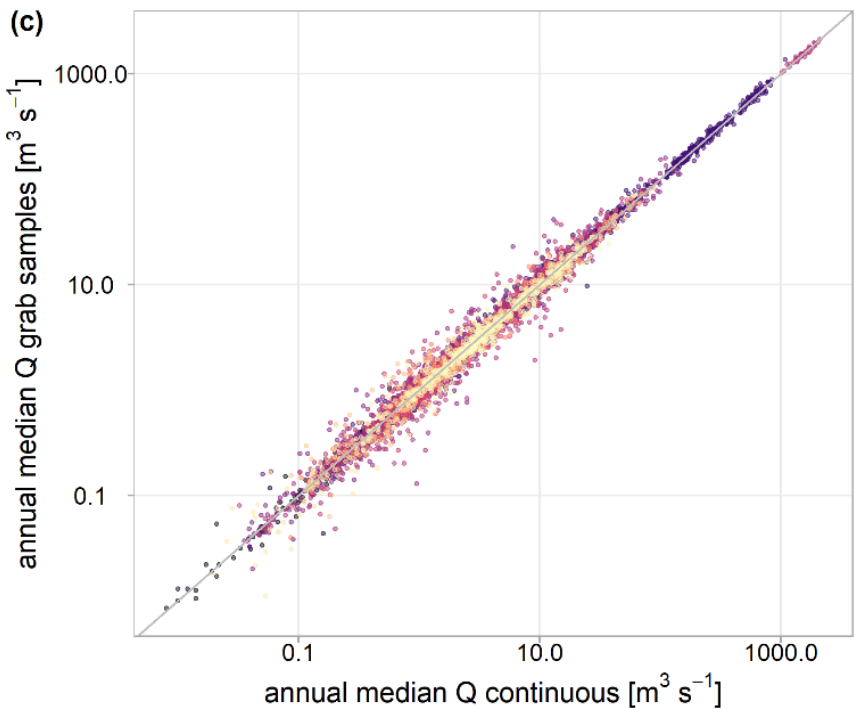

Figure 3: Heat maps of (a) the number of stations with available annual median discharge from daily and grab sample dates, (b) number of years covered per station, and (c) comparison of annual medians from continuous (daily) $Q$ and $Q$ at the dates grab samples were taken. Colors on the right are used for better visibility and distinguish the different catchments.

\subsubsection{Monthly median discharge}

Monthly median discharge is provided for WRTDS stations. To fill gaps in the daily discharge time series of 45 stations required for WRTDS models (see Section 3.1.2), we used simulated discharge from the mesoscale hydrological model $m H M$ (Kumar et al., 2013; Samaniego et al., 2010; Zink et al., 2017) if the regression coefficient $\left(\mathrm{R}^{2}\right)$ between observed and simulated discharge for the station was greater than 0.6. Subsequently, modelled discharge was bias-corrected with piecewise linear regressions and used for gapfilling (Ehrhardt et al., 2021; Ebeling et al., 2021d). If modelled discharge was not available, small gaps (up to seven days) were interpolated with fixed-interval smoothing using the $\mathrm{R}$ package baytrends 285 (Murphy et al., 2019).

\subsubsection{Monthly median discharge over the time series}

Analogously to the water quality metrics (see Section 3.1.3), we provide long-term monthly median discharge over the whole time series if available for the station representing average discharge seasonality. The number of samples used for the calculation of medians is indicated as a measure of accuracy. 


\section{3.3 Meteorological time series}

Meteorological time series are provided as spatial catchment averages on monthly resolution. We used the daily gridded product of climate variables (precipitation and maximum, minimum, and average air temperature) from the European Climate Assessment and Dataset project (E-OBS, v18.0e; Cornes et al., 2018). The advantage of a European data set is the coverage of transnational catchments as e.g. the Elbe

295 or Rhine. The data sets are available at a spatial resolution of 0.1 degree over the period 1950-2018. The interpolation approach used to create the gridded fields uses a stochastic technique based on Gaussian Random Field, and involves several ground-based observation networks distributed across Europe (see Cornes et al., 2018 for more details). The daily fields of potential evapotranspiration are derived based on the method from Hargreaves and Samani (1985) at the same spatial resolution (0.1 degree) using the daily

300 (maximum, minimum and average) air temperature data sets. We then calculated the spatial averages of daily climate variables (precipitation, air temperature, potential evapotranspiration) for all water quality stations, considering the corresponding (upstream) catchment area. Monthly estimates of total precipitation and potential evapotranspiration, and average air temperatures were subsequently calculated for each study basin.

\section{$305 \quad 3.4$ Time series of net $\mathbf{N}$ input from diffuse sources}

For the period 1950-2015, we provide time series of catchment-scale N surplus, i.e. the net diffuse $\mathrm{N}$ input, which is the sum of $\mathrm{N}$ sources minus the sum of $\mathrm{N}$ sinks. At the catchment scale, the $\mathrm{N}$ surplus is the sum of $\mathrm{N}$ surplus on agricultural $\mathrm{N}_{\text {agri }}\left(\mathrm{kg} \mathrm{y}^{-1} \mathrm{ha}^{-1}\right)$ and non-agricultural areas $\mathrm{N}_{\text {nonagri }}\left(\mathrm{kg} \mathrm{y}^{-1} \mathrm{ha}^{-1}\right)$ normalized to the catchment area. For transboundary catchments with area outside of Germany, N surplus

310 is normalized to the German part only. On non-agricultural areas, the $\mathrm{N}$ surplus is composed of atmospheric $\mathrm{N}$ deposition and biological $\mathrm{N}$ fixation. On agricultural areas, the $\mathrm{N}$ surplus includes additional N sources, i.e. mineral fertilizer and manure applications, and N sinks from crop harvesting. For agricultural land, the $\mathrm{N}$ surplus data stem from two data sets: one at state level provided for the period 1950-1998 (Behrendt et al., 2003; which builds on Bach and Frede, 1998; and Behrendt et al., 2000), and

315 one at county level provided for the period 1995-2015 (Häußermann et al., 2019). To create a consistent long-term data set (1950-2015), we harmonized the county and state level data sets based on the 
overlapping years (1995-1998) and downscaled the state level data to county level for the period 19501994. Specifically, we bias-corrected the state level data of Behrendt et al. (2003) using proportions as they commonly underestimated the values provided by Häußermann et al. (2019) for the period 19951998. To downscale the bias-corrected state level N surplus (1950-1994) to county level, we used a linear regression between the county and state totals for the period 1995-2015 (data from Häußermann et al., 2019). As data for city-states (Berlin, Bremen and Hamburg) are not provided in the state level dataset, we used the average value from 1995-1998 for the period 1950-1994 under the assumption that the error is acceptable considering the small agricultural areas. The $\mathrm{N}$ surplus data comprises values for five of the 325 eleven agricultural land classes in Corine Land Cover (CLC; EEA, 2016b) (non-irrigated arable land, vineyards, fruit trees and berry plantations, pastures, complex cultivation patterns). The data includes $\mathrm{N}$ inputs from applications of fertilizers in mineral and organic forms, $\mathrm{N}$ input from seeds and planting material (county level data only), $\mathrm{N}$ deposition and biological $\mathrm{N}$ fixation, and $\mathrm{N}$ outputs from harvested crops. To upscale agricultural $\mathrm{N}$ surplus from county level to catchment level, we used the fraction of agricultural area provided by CLC and a scaling factor. Since CLC overestimates agricultural areas compared to the census data at county level (Bach et al., 2006), we scaled the agricultural areas from CLC in each county with the mean ratio between the agricultural area from census data (Häußermann et al., 2019) and the CLC maps (years 2000, 2006 and 2012; median ratio of 1.24 across counties).

For non-agricultural land (CLC classes forest, water bodies, wetlands, grassland) and the remaining 335 agricultural land CLC classes not covered by the $\mathrm{N}$ surplus data described above (e.g., permanently irrigated land), we used the atmospheric N deposition data from the Meteorological Synthesizing CentreWest (MSC-W) of the European Monitoring and Evaluation Programme (EMEP; Simpson et al., 2012). The EMEP database uses a chemical transport model to generate a consistent gridded field of Europewide wet and dry, and oxidized and reduced atmospheric N depositions (Simpson et al., 2012). The model assimilates varying levels of observational information on different atmospheric chemicals (e.g., Bartnicky and Benedictow, 2017; Bartnicky and Fagerli, 2006). The data was available for the period 1980-1995 with five-year steps, which we linearly interpolated to obtain an annual time series, and with annual steps for the period 1995-2015. For the data before 1980, we assumed constant values from 1980 due to missing information. Deposition on urban sealed surfaces was neglected, since we assume this 
345 component is collected by the sewer system and is therefore not a diffuse $\mathrm{N}$ source, whereas deposition on urban grassland like public parks was considered. To account for the overestimated area of the five agricultural CLC classes of the agricultural $\mathrm{N}$ surplus data (see above), we added the corresponding missing fraction proportionally to the remaining land cover classes. We estimated terrestrial biological $\mathrm{N}$ fixation by plants for non-agricultural, vegetated areas using land-use specific rates provided by 350 Cleveland et al. (1999) and Van Meter et al. (2017).

The catchment scale $\mathrm{N}$ surplus time series were calculated by intersecting the two $\mathrm{N}$ surplus components ( $\mathrm{N}_{\text {agri }}$ and $\mathrm{N}_{\text {nonagri }}$ ) with the respective land use and catchment area. As the $\mathrm{N}$ surplus data was only available within Germany; data from transboundary catchments (e.g., main stretch of the Elbe or Rhine Rivers) need to be used cautiously, with higher uncertainty for catchments with a higher fraction of 355 catchment area outside Germany (Section 4.3). Figure 4 shows the resulting N input time series of all catchments. The majority of $\mathrm{N}$ input stems from agriculture with a median of $64 \%$ of the total catchment $\mathrm{N}$ surplus stemming from $\mathrm{N}_{\text {agri }}$ across all catchments (averages between 1950 and 2015). The agricultural $\mathrm{N}$ surplus ( $\left.\mathrm{N}_{\text {agri }}\right)$ as well as its fraction per catchment was highest during the 1980 s with the median across catchments amounting to $52 \mathrm{~kg} \mathrm{ha}^{-1} \mathrm{y}^{-1}$ and $76 \%$ (average between 1980 and 1989), respectively. The 360 highest mean agricultural $\mathrm{N}$ surplus and its fraction per year across all catchments were reached in 1988 with $60.7 \mathrm{~kg} \mathrm{ha}^{-1} \mathrm{y}^{-1}$ and $74 \%$, while the values were already above $50 \mathrm{~kg} \mathrm{ha}^{-1} \mathrm{y}^{-1}$ and $70 \%$ from 1976 to 1989 . For the total $\mathrm{N}$ surplus, mean annual values across catchments were above $70 \mathrm{~kg} \mathrm{ha}^{-1} \mathrm{y}^{-1}$ in the same period (1976-1989), while values above $50 \mathrm{~kg} \mathrm{ha}^{-1} \mathrm{y}^{-1}$ were already reached since 1969 and the maximum of $76.7 \mathrm{~kg} \mathrm{ha}^{-1} \mathrm{y}^{-1}$ occurred in 1980. 

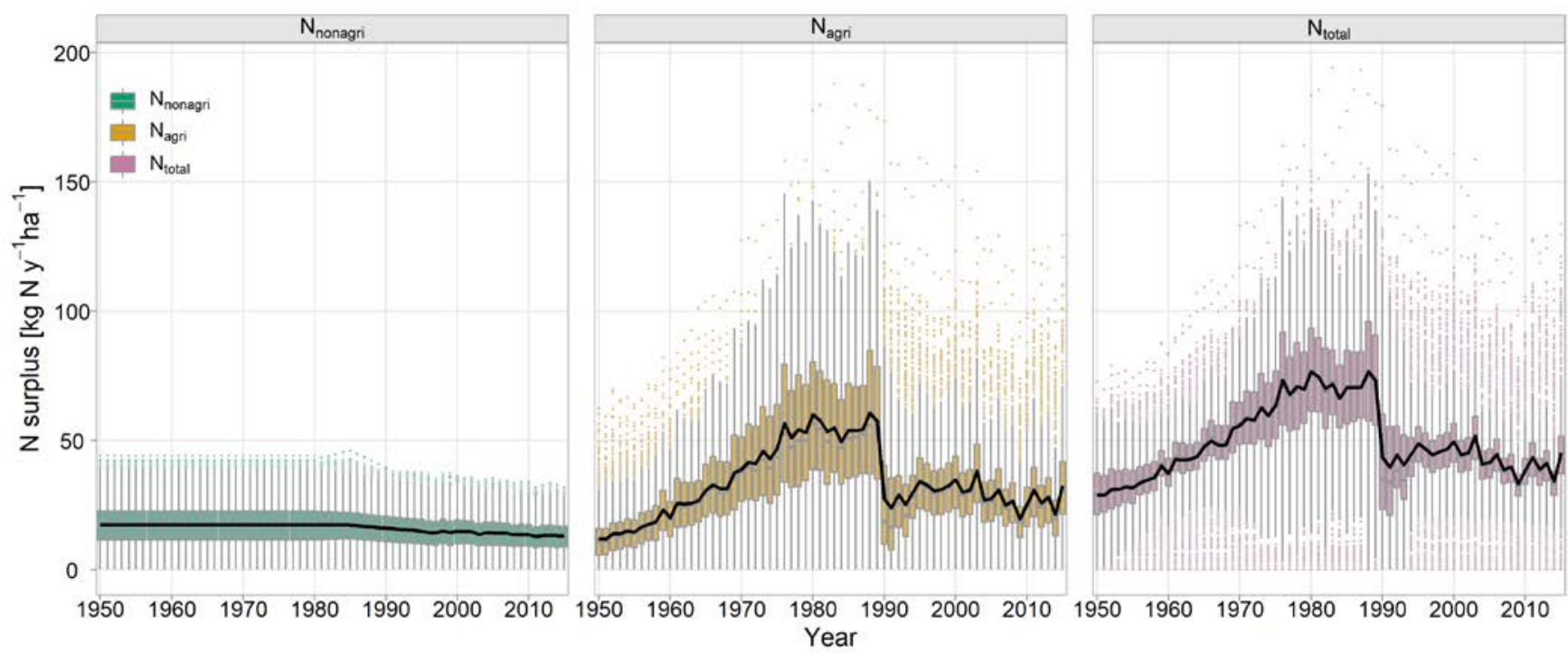

Figure 4: Time series of annual $\mathbf{N}$ surplus of all catchments for the different $\mathbf{N}$ surplus components: $\mathbf{N}$ surplus on non-agricultural areas (left), $\mathbf{N}$ surplus on agricultural areas (middle), and total $\mathbf{N}$ surplus from both non-agricultural and agricultural areas (right). Boxplots represent the distribution of annual $\mathrm{N}$ surplus as averages of the German catchment area across all catchments showing summary statistics (median, quartiles, and quartiles +/- 1.5 times the interquartile range) and individual points outside these ranges. The black lines represent mean annual values for each $\mathrm{N}$ surplus component across the catchments.

\section{Catchment attributes}

The provided catchment attributes characterize the catchments in terms of topography, land cover, nutrient sources, lithology and soils, and hydroclimate. The attributes were chosen with a focus on macronutrient sources and transport in line with the data set. Figure 5 shows the spatial distribution of a set of selected characteristics. All attributes, their variable names, original data sources and methods are listed in Appendix B Table B1 and the data repository (Ebeling et al., 2021a). This repository of catchment attributes is a composite of attributes from two existing repositories (Ebeling and Dupas, 2021; Ebeling, 2021). 
https://doi.org/10.5194/essd-2022-6

Preprint. Discussion started: 1 March 2022

(c) Author(s) 2022. CC BY 4.0 License.

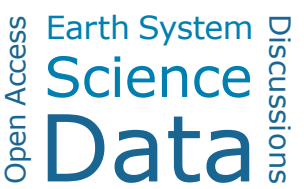
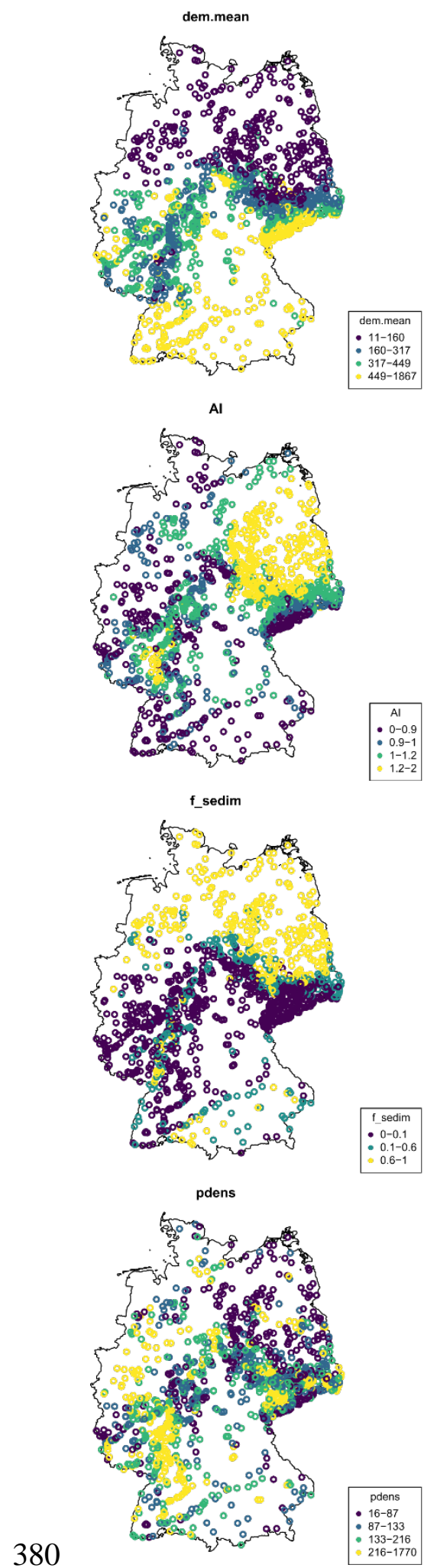
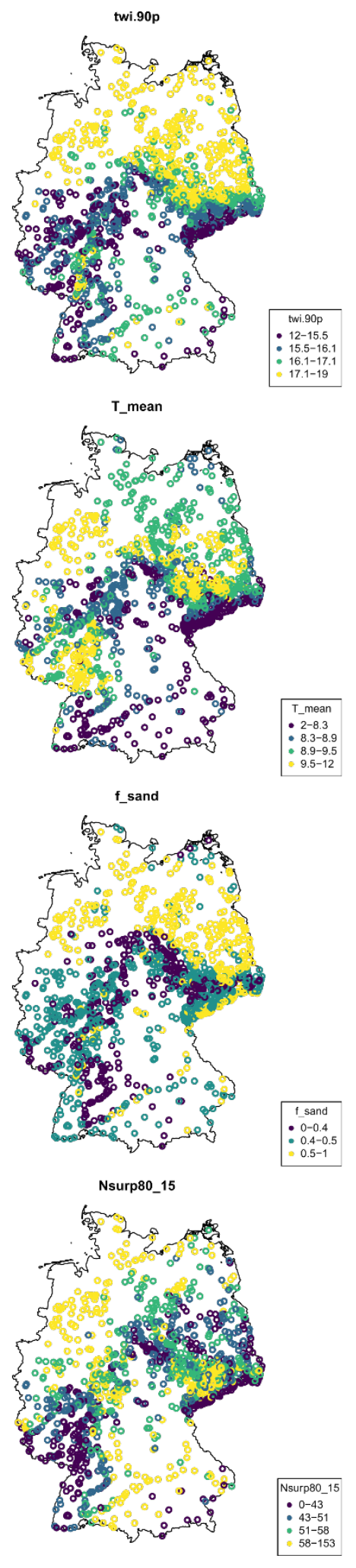
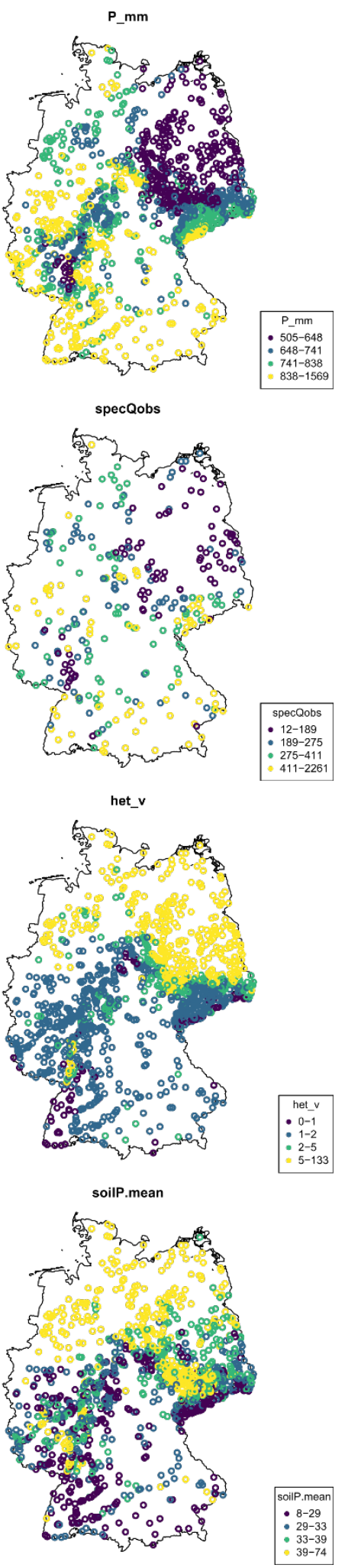
Figure 5: Maps of selected catchment characteristics. Each dot represents one station and the color represents the attribute of the corresponding catchment. Color bars are according to the quartiles of the data distribution of each attribute. Shown attributes: dem.mean - average elevation [m], twi.90p $-90^{\text {th }}$ percentile of the topographic wetness index [-], $\mathbf{P} \_\mathbf{m m}$ - mean annual precipitation $\left[\mathrm{mm} \mathrm{y}^{-1}\right], \mathbf{A I}$ - aridity index [-], T_mean - mean air temperature $\left[{ }^{\circ} \mathrm{C}\right]$, specQobs - specific annual discharge [mm $\left.\mathrm{y}^{-1}\right]$, $\mathrm{f} \_s e d i m$ fraction of sedimentary aquifer [-], f_sand - fraction of sandy soils [-], het_v - vertical concentration heterogeneity [-], pdens population density [inhabitants $\mathrm{km}^{-2}$ ], Nsurp80_15 - mean N surplus from 1980-2015 [kg N ha ${ }^{-1} \mathrm{y}^{-1}$ ], soilP.mean - phosphorus content in topsoil [ $\mathrm{mg} \mathrm{kg}^{-1}$ ]. For more details on the characteristics refer to the text in Section 4 and Table B1.

\subsection{Location and Topography}

Catchment size was calculated from the delineated catchment boundaries described in Section 2.

390 Catchment size ranges from 0.9 to $123,012 \mathrm{~km}^{2}$ with a median of $171.2 \mathrm{~km}^{2}$, a $25^{\text {th }}$ percentile of 53.6 and a $75^{\text {th }}$ percentile of $634.4 \mathrm{~km}^{2}$. Additionally, the fraction of the catchment area lying within German borders was calculated (f_AreaGer). Mean and median catchment elevation and topographic slope were extracted from the DEM with $100 \mathrm{~m}$ resolution (see also Section 2; EEA, 2013). The $100 \mathrm{~m}$ grid of topographic wetness index (TWI) was calculated from the DEM by relating the upstream area (from flow accumulation) to the local slope at each grid cell following Beven and Kirkby (1979). For each catchment, we extracted mean, median and $90^{\text {th }}$ percentile TWI values. The $90^{\text {th }}$ percentile has been shown to be a proxy for the abundance of riparian wetlands in a catchment (Musolff et al., 2018). Drainage density, defined as the length of surface waters per area, closely relates to topography. Drainage density was calculated and provided in two ways: as the catchment average of the gridded drainage density (cell size 0.012 degree) provided in the Hydrologischer Atlas Deutschland (BMU, 2000) and as the river length from EU-hydro river network (EEA, 2016a) within the catchment divided by its area. For the latter, the level of detail was too coarse to yield plausible values for all catchments, which is why values are missing for 27 of the smaller catchments. However, the EU-hydro river network allowed us to derive further stream attributes such as the Strahler order.

\subsection{Land cover and population density}

The fractions of land cover classes were calculated from the level 1 classification of the CLC data set for 2012 (artificial, agricultural, forested land, wetland and surface water cover) (EEA, 2016b). For a finer distinction within these overall classes, fractions of land cover classes were additionally calculated from level 2 data. Note that there can be an overestimation of agricultural areas from these CLC land cover 410 classes when compared to census data as described by Bach et al. (2006) and considered for N surplus 
time series (Section 3.4). Nevertheless, we expect that the relative distribution of agricultural fractions among the catchments is well captured. The mean catchment population density was calculated from the global data set Gridded Population of the World (CIESIN, 2017) for 2010.

\subsection{Nutrient sources}

415 The input from point sources is calculated as the sum of $\mathrm{N}$ and P load from wastewater treatment plants (WWTPs) with more than 2000 population equivalents (PE) from the database of the European Environment Agency (EEA, 2017) and data collected from 13 German federal states covering smaller WWTPs (PE < 2000) within Germany (Büttner, 2020). One PE is defined as the organic biodegradable load having a five-day biochemical oxygen demand (BOD5) of $60 \mathrm{~g}$ of oxygen per day (EC, 1991b). As

420 a second data source, we calculated catchment averages of the European domestic waste emissions database (Vigiak et al., 2019; Vigiak et al., 2020) for N, P and BOD5 inputs from point sources. The average N, P und BOD5 input per person was estimated using the point source input divided by the number of inhabitants according to the population density. The advantage of these European data is the consistency for an extended, transnational data set, for example, as it is available for German and French

425 catchments (Ebeling and Dupas, 2021).

The net $\mathrm{N}$ input from diffuse sources was determined as temporal averages of diffuse $\mathrm{N}$ surplus time series (Section 3.4) for different periods, representing the main sampling period with historic inputs (1980-2015) and the current period (2000-2015). We also calculated averages for the periods before (1971-1990) and after (1990-2015) the EU Nitrogen Directive (EC, 1991a) and the difference between 430 them as a characteristic of net input change. Note that the used N surplus data only cover Germany, but catchments can be transnational. The uncertainty with larger areas outside of Germany increases, for which f_AreaGer can be used as a measure. To estimate source apportionment between point and diffuse $\mathrm{N}$ sources, we calculated the fraction of catchment point source N loads (N_WW_frac) from total catchment $\mathrm{N}$ input as the sum of catchment point source $\mathrm{N}$ loads (N_T_YKM2) and $\mathrm{N}$ surplus (here using 435 Nsurp80_15 for the period 1980-2015) on average based on the European wastewater database.

$$
\text { N_WW_frac }=\text { N_T_YKM2/(N_T_YKM2 }+ \text { Nsurp80_15) }
$$


We defined horizontal and vertical source heterogeneity in catchments to quantify the spatial distribution of diffuse nutrient sources with a focus on $\mathrm{NO}_{3}-\mathrm{N}$ (Ebeling et al., 2021c). The horizontal source heterogeneity describes the distribution of agricultural land use in a catchment in relation to the stream 440 network. We used the horizontal flow distance of the $100 \mathrm{~m}$ DEM (EEA, 2013; Section 2) to the EUhydro river network (EEA, 2016a) and a highly resolved land use map of 2015 provided by Pflugmacher et al. (2018). We divided the grid into classes of flow distance to stream with $400 \mathrm{~m}$ steps. Subsequently, we fitted a linear regression to the share of agricultural source areas in each of the distance classes and the mean distance of the range of each distance class (i.e., $200 \mathrm{~m}$ for the class 0-400 $\mathrm{m}$ ) weighted by the

445 abundance of that specific class. The slope of the resulting linear model het_h characterizes if agricultural source areas tend to be located close to the stream network (het_h $<0$ ), equally distributed (het_h=0) or located far away from the stream network (het_h>0). For more details refer to Ebeling et al. (2021c). The vertical source heterogeneity het_v is the ratio of shallow and deep $\mathrm{NO}_{3}-\mathrm{N}$ concentration. Shallow $\mathrm{NO}_{3}$ N concentrations are estimated on a $1 \mathrm{~km}$ grid by Knoll et al. (2020) using a ten years average of N surplus

450 and average groundwater recharge. This can be seen as a potential leachate concentration as denitrification in the soil's root zone and horizontal transport are not accounted for. The deep $\mathrm{NO}_{3}-\mathrm{N}$ concentrations are estimated on the same grid using a random forest model that is trained on observed concentrations in groundwater (Knoll et al., 2020). The ratio of both was averaged across the catchment to yield het_v reported here. A ratio of one describes a catchment that has a vertical homogeneity in $\mathrm{NO}_{3}-\mathrm{N}$ concentrations while a ratio above one describes stronger vertical concentration gradients.

\subsection{Lithology and Hydrogeology}

To characterize the lithological and the hydrogeological settings of the catchments we used the international hydrogeological map of Europe 1:1,500,00 (BGR \& UNESCO, 2014). For the lithological settings, we derived the fraction of area covered by calcareous rocks, calcareous rocks and sediments,

460 magmatic rocks, metamorphic rocks, siliciclastic rocks, siliciclastic rocks and sediments, and sediments (based on lithology data level four). Additionally, we determined the fractions of the more aggregated lithological classes (from lithology level five), i.e. consolidated, partly consolidated, and unconsolidated rocks. We furthermore quantified the areal fraction of aquifer type in the catchment differentiating porous 
aquifers, fissured hard rock aquifers (including karst), and locally aquiferous or non-aquiferous rocks.

465 Finally, we extracted the catchment median estimate of depth to bedrock from the global map from Shangguan et al. (2017).

\subsection{Soil properties}

We calculated the fraction of the catchment covered with hydromorphic soils (stagnosols, semi-terrestrial, semi-subhydric, subhydric and peat soils) from the German soil map (1:250,000; BGR, 2018). As this data source only covers Germany, data might not be reliable for transboundary catchments (see also Section 4.3). We also calculated the average fraction of sand, silt and clay averaged across the soil horizons of the top $1 \mathrm{~m}$ based on the Harmonized World Soil Database (HWSD; v1.2) available at a 30 arc-second raster database (FAO/IIASA/ISRIC/ISSCAS/JRC, 2012). We first estimated vertically weighted soil textural properties from the original HWSD data provided for two soil layers (upper $30 \mathrm{~cm}$ and 30-100 cm). Next, we calculated the areal averages of respective properties considering the boundary (polygon) of each study catchment.

We estimated the porosity of soil profiles (thetaS) based on the pedo-transfer function of Zacharias and Wessolek (2007) and the root-zone plant available water content (WaterRoots) which reflects the difference in water content between the field capacity and permanent wilting point. The field capacity is 480 calculated based on a flux-based estimation approach proposed by Twarakavi et al. (2009) corresponding to a minimum drainage flux of $1 \mathrm{~mm} \mathrm{~d}^{-1}$. The estimate of the permanent wilting point is derived using the Van Genuchten (1980) model of the matric potential at $-1500 \mathrm{kPa}$ and the corresponding model parameters calculated from pedotransfer functions of Zacharias and Wessolek (2007). Similar to soil textural properties, for each of these soil hydraulic parameters (porosity, field capacity, and permanent 485 wilting point), we calculated areal averages of the vertically weighted estimates for the upper $1 \mathrm{~m}$ soil profile for each study catchment. More details on this method using pedo-transfer functions and subsequent aggregations can be found in Livneh et al. (2015). Furthermore, we estimated average catchment soil chemistry of the topsoil (first $20 \mathrm{~cm}$ ) for year 2009 from the European soil chemistry map, which is based on the LUCAS database (Ballabio et al., 2019). For this, we calculated mean C/N ratio, nitrogen content and phosphorus content from the maps for each catchment. 


\subsection{Hydroclimatic characteristics}

Long-term average hydroclimatic characteristics were derived from the meteorological (Section 3.3) and discharge time series. All climatic characteristics were calculated for a period of 30 years from 1986 to 2015 based on the E-OBS data set from the European Climate Assessment \& Dataset (ECA\&D) project

495 (v18.0e; Cornes et al., 2018). First, we provide mean annual precipitation, mean annual potential evapotranspiration, mean annual air temperature and the aridity index as the ratio between potential evapotranspiration and precipitation. The variability of precipitation is further characterized by the mean precipitation frequency and depth (Botter et al., 2013) and by two seasonality indices, i.e. the ratio between summer (June-August) and winter (December-February) precipitation (P_SIsw) and the average difference between average daily precipitation within each month and within a year (P_SI).

The hydrologic properties were characterized from stations with observed daily discharge data (Section 3.2) for different time periods according to the available data and study purposes of the original data sets. For current properties, daily discharge data from November 1999 (hydrological year 2000) were used for calculations (309 stations). Additionally, the hydrologic characteristics calculated from daily discharge data starting in 1986 are provided (319 stations), which are possibly more relevant for studies with a long-term perspective. If there was data only before 1986, we used the available time period (four stations). The actual starting and ending dates of the time series finally used for calculations are provided to inform on the exact time periods (StartQobs and EndQobs; Q_StartDate and Q_EndDate respectively, refer to Table B1). Provided average characteristics include mean, median, median summer (May510 October), median winter (November-April), and specific discharge. For the variability of discharge, we provide the coefficient of variation, the base flow index (according to WMO, 2008) and the flashiness index based on flow percentiles (ratio of $5^{\text {th }}$ to $95^{\text {th }}$ percentile) as well as discharge seasonality in terms of the ratio between summer and winter median discharge and the runoff coefficient (discharging fraction of precipitation). 


\section{Limitations}

The presented data set has several limitations. More than half of the stations do not a have co-located gauging station and the ones that do are not homogeneously distributed across Germany. Existing concentration time series would benefit from available discharge data, as this allows the characterization of concentration-discharge relationships as well as the estimation of daily concentration, flow-normalized concentration and flux data for stations with high data availability using the WRTDS method. Generally, modelled discharge from hydrological models such as mHM (Section 3.2.2) or estimated discharge using other (mechanistic or statistical modeling) techniques could serve to extend the data set of joint water quality and water quantity and overcome missing station matches or data gaps. Other limitations are linked to data policies by federal state authorities, which sometimes do not permit publication of raw

525 quality and quantity data. However, we aimed to make a virtue of necessity by providing aggregated data and further ready-to-use metrics of water quality and quantity (e.g., annual median concentrations and monthly median concentrations over the whole time series). Attributes derived from exclusively national data sets, such as $\mathrm{N}$ surplus, underlie higher uncertainties in transboundary catchments, as data outside Germany are either not available or not consistent. Additionally, there is uncertainty in the attributes, 530 stemming from the inherent uncertainties in the data sets and the catchment boundaries. However, the provided description and references of the methods and the underlying data sources should enable users to evaluate the reliability of each descriptor in the data set and exclude stations from the analyses if necessary. This also leaves room for further improvements and extensions when new data and knowledge become available. Besides a higher number of water quality stations, longer time series and more co535 located discharge data, it would be especially interesting to add time series of nutrient inputs from point sources and from diffuse $\mathrm{P}$ sources, as well as information on tile drainage locations to the catchment attributes. For a better linkage of chemical water quality with ecological research questions, biological water quality variables such as chlorophyll-a concentrations would be highly valuable as well. 


\section{Data availability}

540 The QUADICA data set presented here is freely available in two online repositories. The water quality and water quantity data described in this manuscript, as well as the time series of meteorological and diffuse nitrogen input can be accessed under https://doi.org/10.4211/hs.26e8238f0be14fa1a49641cd8a455e29 (Ebeling et al., 2021b). The catchment characteristics and boundaries are published under

545 https://doi.org/10.4211/hs.82f8094dd61e449a826afdef820a2c19 (Ebeling et al., 2021a). Due to license agreements, the raw concentration and raw discharge data provided by the German federal states are not made public but are deposited in an institutional repository (Musolff et al., 2020), however, metadata of the data and stations are provided under https://doi.org/10.4211/hs.a42addcbd59a466a9aa56472dfef8721 (Musolff, 2020).

\section{Conclusions}

In this study, we provide a comprehensive homogenized data set for 1386 German catchments including time series of water quality, co-located discharge, hydroclimatic data and diffuse nitrogen inputs, as well as catchment boundaries and more than 100 catchment attributes. The presented QUADICA (water QUAlity, DIscharge and Catchment Attributes for large-sample studies in Germany) data set offers the 555 opportunity to identify spatial and temporal patterns in water quality jointly with water quantity. This allows to formulate and test hypotheses on underlying processes by linking observed responses to the driving forces and catchment attributes. QUADICA also opens up opportunities to calibrate and validate water and solute transport models at the scale of single and multiple catchments as well as at national scale. Consequently, the data set has the potential to advance our understanding about water quality processes across scales. More specifically, the data can be used to examine various spatio-temporal water quality patterns such as average concentrations, trends, and average seasonality. For stations with high data availability, analyses can be extended to trajectories of seasonality, flow-normalized concentrations and mass fluxes. The patterns can be investigated for the three different macronutrients nitrogen, phosphorus and organic carbon, their species as well as for nutrient ratios. In addition, interactions 
565 between the nutrients and their spatio-temporal patterns can be assessed. In the context of comparative large-sample hydrology (e.g., Gupta et al., 2014), the spatio-temporal water quality patterns can be linked to catchment attributes to identify underlying processes. This can, for example, support quantifying the impact of human disturbances on nutrient cycles and their interactions with natural controls. Some studies investigated spatio-temporal patterns and underlying controls in large-sample approaches using parts of 570 the provided data set recently. For example, Ebeling et al. (2021c) assessed average nutrient concentrations and export dynamics, Ebeling et al. (2021d) evaluated long-term trajectories of nitrate seasonality, Ehrhardt et al. (2021) quantified nitrogen legacies using nitrogen input and export time series, and Yang et al. (2021) modeled the impact of phosphorus inputs on stream network algae growth. These assessments and derived hypotheses can be further explored and extended with the provided data to 575 increase our knowledge on catchment functioning.

Furthermore, the provided data can be merged with other water quality and quantity data sets e.g. to enable assessments across transnational, large scales and with higher variability in catchment attributes. Here, we hope to stimulate other researchers or environmental authorities to provide similar data sets of joint water quality and quantity data to make the wealth of spatiotemporal water quality data available, 580 including long-term data that have been collected in research projects and during regular monitoring activities such as the EU Water Framework Directive (EC, 2000). Therefore, we call for joint efforts to further increase opportunities for catchment scale water quality assessments and modeling activities on regional, transnational and even continental scales. 
https://doi.org/10.5194/essd-2022-6

Preprint. Discussion started: 1 March 2022

(c) Author(s) 2022. CC BY 4.0 License.

\section{Appendix A}
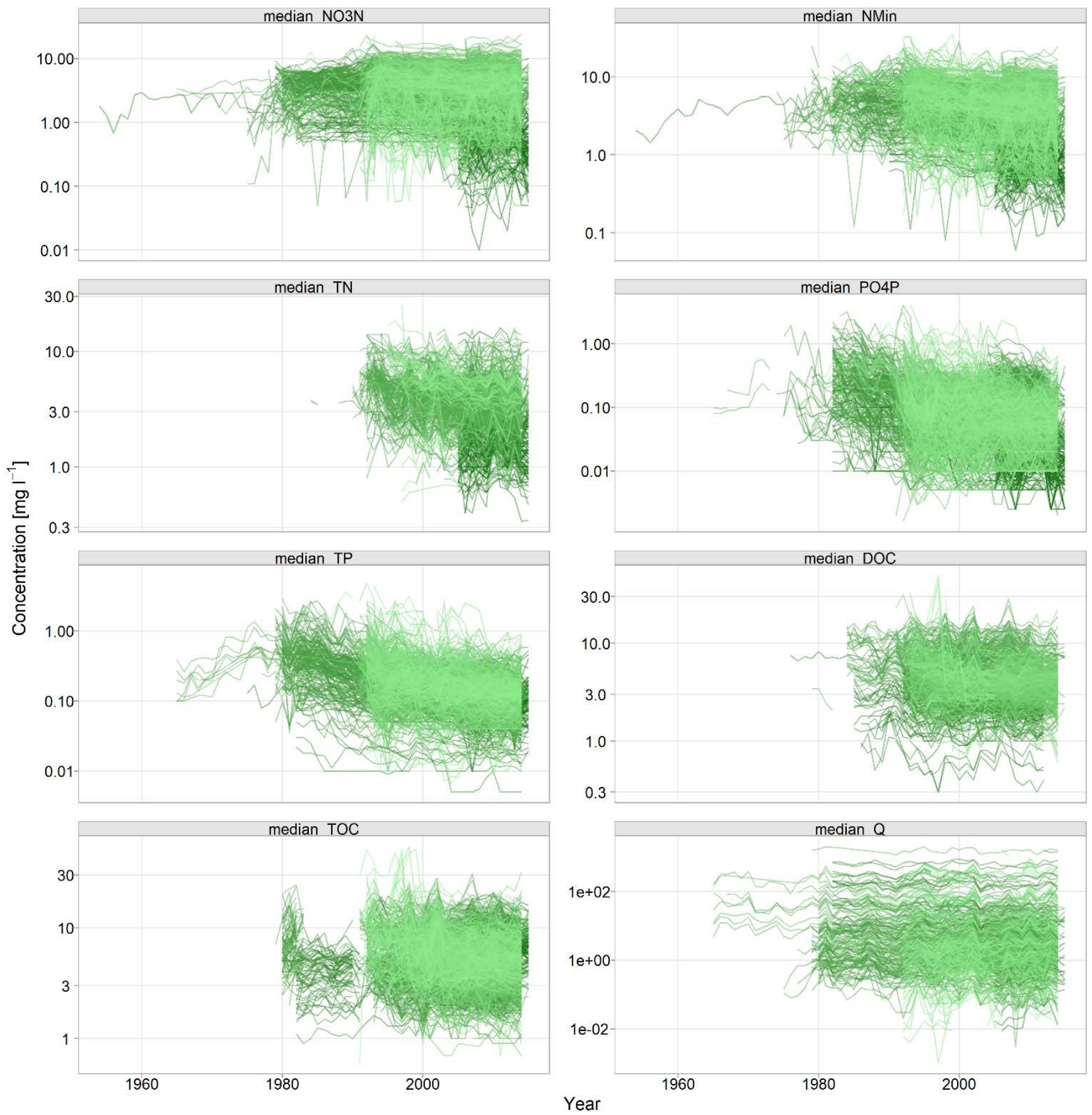

Fig. A1: Time series of annual median concentrations and discharge observed at the 1386 water quality stations during grab sampling as in Table 1, Fig. 1 and described in Section 3.1. Note: For visualization purposes, values $>40 \mathrm{mg} \mathrm{l}^{-1}$ are not shown for $\mathrm{N}$ species (i.e. five $\mathrm{NO}_{3}-\mathrm{N}$, seven $\mathrm{N}_{\min }$ and zero $\mathrm{TN}$ values) and one sample in 1900 has been omitted. 
https://doi.org/10.5194/essd-2022-6

Preprint. Discussion started: 1 March 2022

(c) Author(s) 2022. CC BY 4.0 License.

(c) (i)
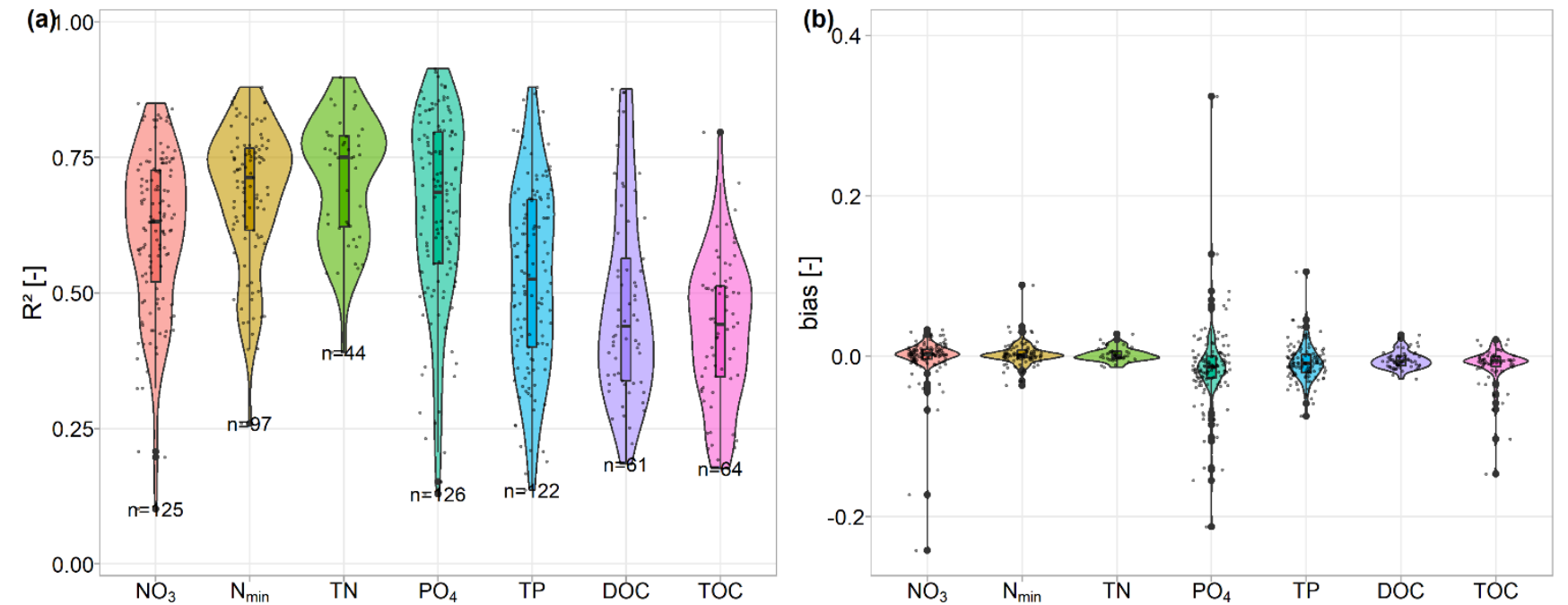

Fig. A2: Distribution of performances of WRTDS-models by compound, coefficient of determination $\mathbf{R}^{2}$ (a) and bias (b). Boxes highlight the median and quartiles of each distribution; points display performance values of single catchments. Note that one bias value $>0.4$ is not shown for TOC for better visibility.

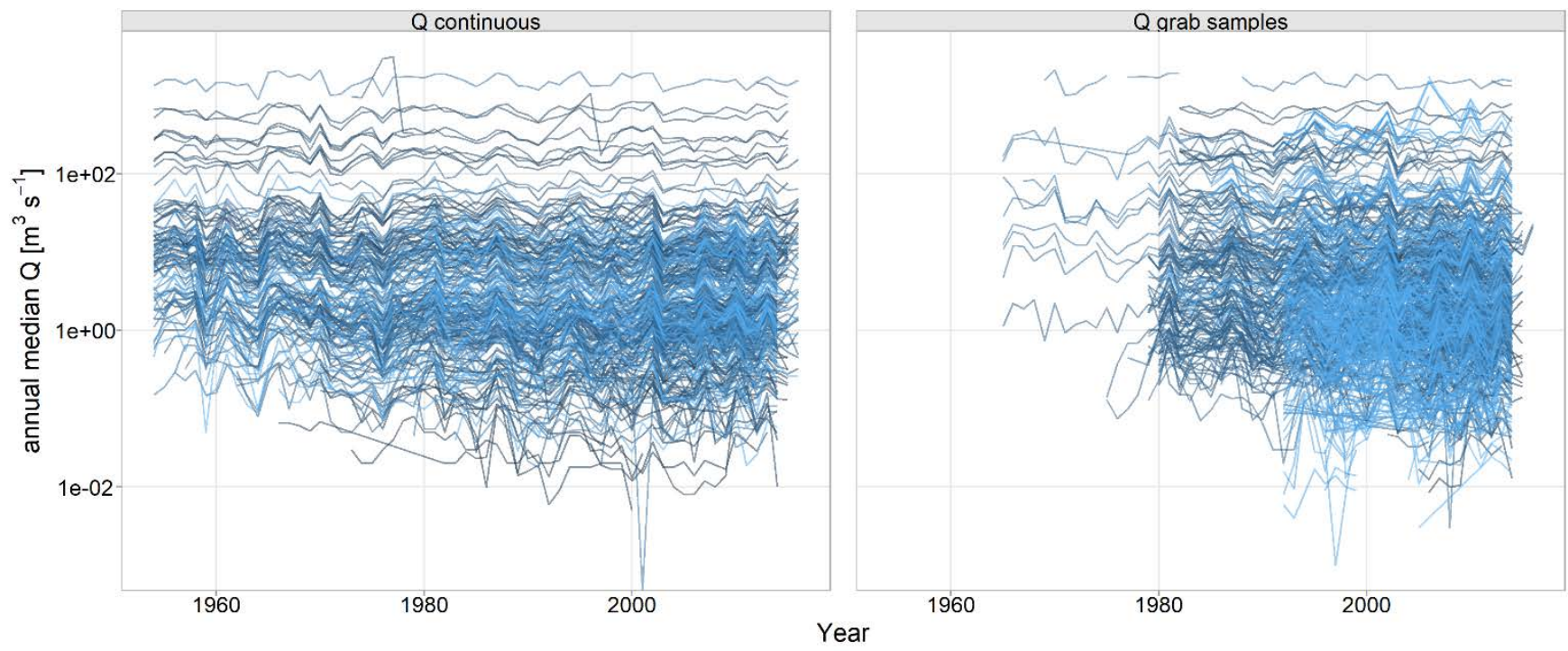

595 Fig. A3: Time series of annual median discharge $\mathbf{Q}$ from (a) 324 stations with continuous observations and (b) 581 stations with observations during grab sampling. Note that stations with continuous discharge data from (a) are included in (b) using only the days of grab sampling for calculation. For visualization purposes only values from 1954 are shown. 
https://doi.org/10.5194/essd-2022-6

Preprint. Discussion started: 1 March 2022

(c) Author(s) 2022. CC BY 4.0 License.

(c) (1)

\section{Appendix B}

Table B1: Catchment attributes, associated methods and original data sources used for calculating the attributes (Ebeling et al., 2021a). This collection of catchment attributes is merged and adapted from existing repositories (Ebeling, 2021; Ebeling and Dupas, 2021) and the related publications (Ebeling et al., 2021d; Ebeling et al., 2021c; Ehrhardt et al., 2021). For more details see Section 4.

\begin{tabular}{|c|c|c|c|c|}
\hline Category & Variable & Unit & Description and method & Data source \\
\hline \multirow[t]{4}{*}{ General } & OBJECTID & - & Unique identifier & \\
\hline & Station & - & Station name & \\
\hline & Area_km2 & $\mathrm{km}^{2}$ & Catchment area & \\
\hline & f_AreaGer & - & Fraction of catchment area within Germany & \\
\hline \multirow[t]{9}{*}{ Topography } & dem.mean & mamsl & $\begin{array}{l}\text { Mean elevation of catchment, from DEM } \\
\text { rescaled from } 25 \text { to } 100 \mathrm{~m} \text { resolution using } \\
\text { average }\end{array}$ & EEA (2013) \\
\hline & dem.median & mamsl & $\begin{array}{l}\text { Median elevation of catchment, from DEM } \\
\text { rescaled from } 25 \text { to } 100 \mathrm{~m} \text { resolution using } \\
\text { average }\end{array}$ & EEA (2013) \\
\hline & slo.mean & $\circ$ & $\begin{array}{l}\text { Mean topographic slope of catchment, from } \\
\text { DEM }\end{array}$ & EEA (2013) \\
\hline & slo.median & $\circ$ & $\begin{array}{l}\text { Median topographic slope of catchment, from } \\
\text { DEM }\end{array}$ & EEA (2013) \\
\hline & twi.mean & - & $\begin{array}{l}\text { Mean topographic wetness index (TWI, Beven } \\
\text { \& Kirkby, 1979) }\end{array}$ & EEA (2013) \\
\hline & twi.med & - & $\begin{array}{l}\text { Median topographic wetness index (TWI, Beven } \\
\text { \& Kirkby, 1979) }\end{array}$ & EEA (2013) \\
\hline & twi.90p & - & $\begin{array}{l}90^{\text {th }} \text { percentile of the TWI as a proxy for riparian } \\
\text { wetlands (following Musolff et al., 2018) }\end{array}$ & EEA (2013) \\
\hline & ddhad & $\mathrm{km}^{-1}$ & $\begin{array}{l}\text { Average drainage density of the catchment. } \\
\text { Gridded drainage density is provided as the } \\
\text { length of surface waters (rivers and lakes) per } \\
\text { area from a } 75 \mathrm{~km}^{2} \text { circular area around each cell } \\
\text { centerd. }\end{array}$ & BMU (2000) \\
\hline & DrainDens & $\mathrm{km}^{-1}$ & $\begin{array}{l}\text { Average drainage density of the catchment, } \\
\text { calculated from EU-Hydro River Network and } \\
\text { intersection with Catchment polygons (contains } \\
\text { several implausible values (often too small } \\
\text { values due to coarser resolution of river } \\
\text { network)) }\end{array}$ & EEA (2016b) \\
\hline Land cover & f_artif & - & Fraction of artificial land cover & EEA (2016a) \\
\hline
\end{tabular}




\begin{tabular}{|c|c|c|c|c|}
\hline & f_agric & - & Fraction of agricultural land cover & EEA (2016a) \\
\hline & f_forest & - & Fraction of forested land cover & EEA (2016a) \\
\hline & f_wetl & - & Fraction of wetland cover & EEA (2016a) \\
\hline & f_water & - & Fraction of surface water cover & EEA (2016a) \\
\hline & f_urban & - & $\begin{array}{l}\text { Fraction of Class } 11 \text { Level } 2 \text { CORINE Land } \\
\text { Cover }\end{array}$ & EEA (2016a) \\
\hline & f_industry & - & $\begin{array}{l}\text { Fraction of Class } 12 \text { Level } 2 \text { CORINE Land } \\
\text { Cover }\end{array}$ & EEA (2016a) \\
\hline & f_mine & - & $\begin{array}{l}\text { Fraction of Class } 13 \text { Level } 2 \text { CORINE Land } \\
\text { Cover }\end{array}$ & EEA (2016a) \\
\hline & f_urban_veg & - & $\begin{array}{l}\text { Fraction of Class } 14 \text { Level } 2 \text { CORINE Land } \\
\text { Cover }\end{array}$ & EEA (2016a) \\
\hline & f_arable & - & $\begin{array}{l}\text { Fraction of Class } 21 \text { Level } 2 \text { CORINE Land } \\
\text { Cover }\end{array}$ & EEA (2016a) \\
\hline & f_agri_perm & - & $\begin{array}{l}\text { Fraction of Class } 22 \text { Level } 2 \text { CORINE Land } \\
\text { Cover }\end{array}$ & EEA (2016a) \\
\hline & f_pastures & - & $\begin{array}{l}\text { Fraction of Class } 23 \text { Level } 2 \text { CORINE Land } \\
\text { Cover }\end{array}$ & EEA (2016a) \\
\hline & f_agri_hetero & - & $\begin{array}{l}\text { Fraction of Class } 24 \text { Level } 2 \text { CORINE Land } \\
\text { Cover }\end{array}$ & EEA (2016a) \\
\hline & f_fores & - & $\begin{array}{l}\text { Fraction of Class } 31 \text { Level } 2 \text { CORINE Land } \\
\text { Cover }\end{array}$ & EEA (2016a) \\
\hline & f_scrub & - & $\begin{array}{l}\text { Fraction of Class } 32 \text { Level } 2 \text { CORINE Land } \\
\text { Cover }\end{array}$ & EEA (2016a) \\
\hline & f_open & - & $\begin{array}{l}\text { Fraction of Class } 33 \text { Level } 2 \text { CORINE Land } \\
\text { Cover }\end{array}$ & EEA (2016a) \\
\hline & pdens & $\begin{array}{l}\text { inhabitants } \\
\mathrm{km}^{-2}\end{array}$ & Mean population density & CIESIN (2017) \\
\hline $\begin{array}{l}\text { Nutrient } \\
\text { sources }\end{array}$ & Nsurp00_15 & $\mathrm{kg} \mathrm{N} \mathrm{ha}^{-1} \mathrm{y}^{-1}$ & $\begin{array}{l}\text { Mean nitrogen (N) surplus per catchment during } \\
\text { sampling period (2000-2015) including the N } \\
\text { surplus on agricultural land and atmospheric N } \\
\text { deposition and biological N fixation on non- } \\
\text { agricultural areas. Details on the N surplus data } \\
\text { is given in Section 3.4. }\end{array}$ & 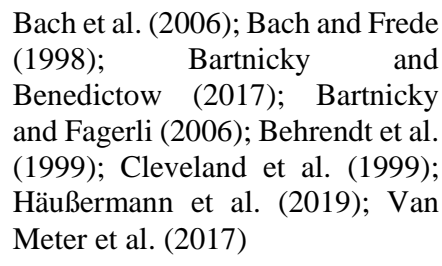 \\
\hline & Nsurp91_15 & kg N ha ${ }^{-1} y^{-1}$ & $\begin{array}{l}\text { Mean N surplus per catchment from } 1991 \text { to } \\
2015 \text { (after Nitrogen Directive was introduced) }\end{array}$ & See Nsurp00_15 \\
\hline
\end{tabular}




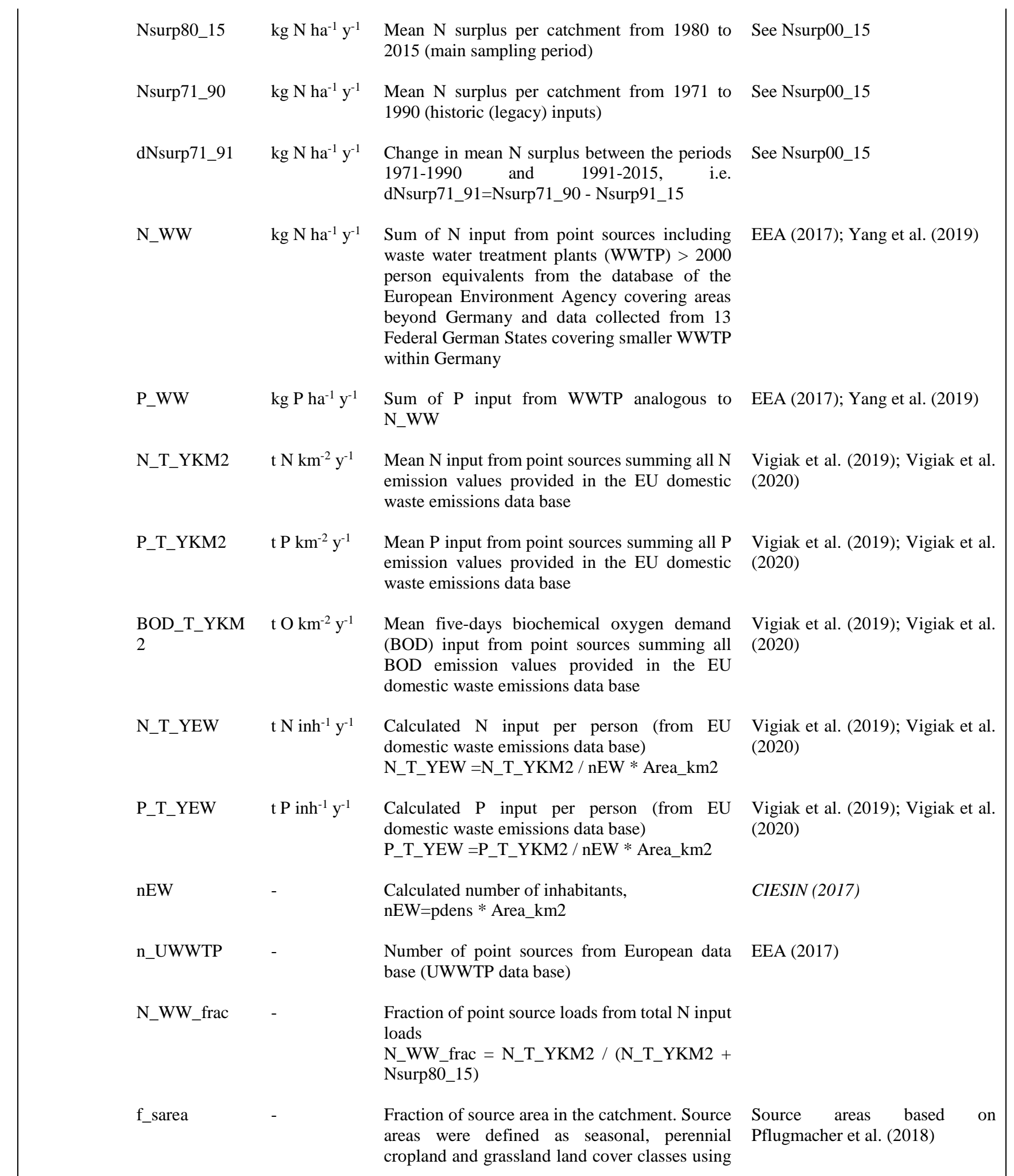




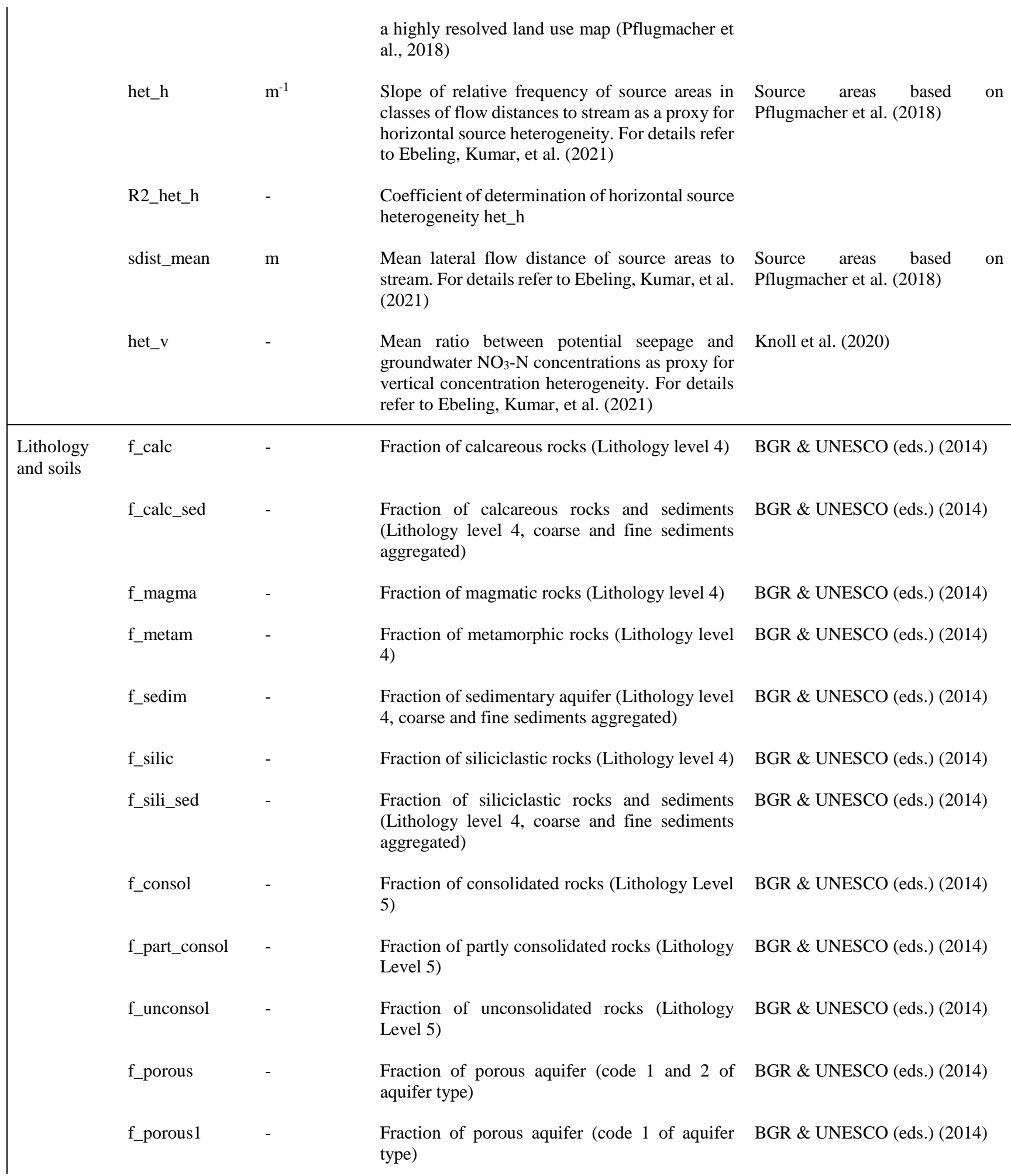




\begin{tabular}{|c|c|c|c|}
\hline f_porous2 & - & $\begin{array}{l}\text { Fraction of porous aquifer (code } 2 \text { of aquifer } \\
\text { type) }\end{array}$ & BGR \& UNESCO (eds.) (2014) \\
\hline f_fissured & - & $\begin{array}{l}\text { Fraction of fissured aquifer (code } 3 \text { and } 4 \text { of } \\
\text { aquifer type) }\end{array}$ & BGR \& UNESCO (eds.) (2014) \\
\hline f_fiss1 & - & $\begin{array}{l}\text { Fraction of fissured aquifer (code } 3 \text { of aquifer } \\
\text { type) }\end{array}$ & BGR \& UNESCO (eds.) (2014) \\
\hline f_fiss2 & - & $\begin{array}{l}\text { Fraction of fissured aquifer (code } 4 \text { of aquifer } \\
\text { type) }\end{array}$ & BGR \& UNESCO (eds.) (2014) \\
\hline f_hard & - & $\begin{array}{l}\text { Fraction of locally aquiferous and non- } \\
\text { aquiferous aquifer (code } 5 \text { and } 6 \text { of aquifer type) }\end{array}$ & BGR \& UNESCO (eds.) (2014) \\
\hline f_hard1 & - & $\begin{array}{l}\text { Fraction of locally aquiferous rocks (code } 5 \text { of } \\
\text { aquifer type) }\end{array}$ & BGR \& UNESCO (eds.) (2014) \\
\hline f_hard2 & - & $\begin{array}{l}\text { Fraction of non-aquiferous rocks (code } 6 \text { of } \\
\text { aquifer type) }\end{array}$ & BGR \& UNESCO (eds.) (2014) \\
\hline f_inwater & & $\begin{array}{l}\text { Fraction of inland water (code } 200 \text { of aquifer } \\
\text { type) }\end{array}$ & BGR \& UNESCO (eds.) (2014) \\
\hline f_ice & & $\begin{array}{l}\text { Fraction of snow or ice field (code } 300 \text { of aquifer } \\
\text { type) }\end{array}$ & BGR \& UNESCO (eds.) (2014) \\
\hline dtb.median & $\mathrm{cm}$ & Median depth to bedrock in the catchment & Shangguan et al. (2017) \\
\hline f_gwsoils & - & $\begin{array}{l}\text { Fraction of water-impacted soils in the } \\
\text { catchment (from soil map 1:250,000), including } \\
\text { stagnosols, semi-terrestrial, semi-subhydric, } \\
\text { subhydric and moor soils }\end{array}$ & BGR (2018) \\
\hline $\begin{array}{l}\text { f_sand } \\
\text { f_silt } \\
\text { f_clay }\end{array}$ & - & $\begin{array}{l}\text { Mean fraction of sand in soil horizons of the top } \\
100 \mathrm{~cm} \\
\text { Mean fraction of silt in soil horizons of the top } \\
100 \mathrm{~cm} \\
\text { Mean fraction of clay in soil horizons of the top } \\
100 \mathrm{~cm}\end{array}$ & $\begin{array}{l}\text { FAO/IIASA/ISRIC/ISSCAS/JRC } \\
(2012)\end{array}$ \\
\hline f_clay_agri & & $\begin{array}{l}\text { Mean fraction of clay in soil horizons of the top } \\
100 \mathrm{~cm} \text { on agricultural land use (Class } 2 \text { Level } 1 \\
\text { CORINE; see f_clay and f_agric) }\end{array}$ & $\begin{array}{l}\text { FAO/IIASA/ISRIC/ISSCAS/JRC } \\
\text { (2012), EEA (2016a) }\end{array}$ \\
\hline WaterRoots & $\mathrm{mm}$ & $\begin{array}{l}\text { Mean available water content in the root zone } \\
\text { from pedo-transfer functions }\end{array}$ & $\begin{array}{l}\text { Livneh et al. (2015); Samaniego et } \\
\text { al. (2010); Zink et al. (2017) }\end{array}$ \\
\hline thetaS & - & $\begin{array}{l}\text { Mean porosity in catchment from pedo-transfer } \\
\text { functions }\end{array}$ & $\begin{array}{l}\text { Livneh et al. (2015); Samaniego et } \\
\text { al. (2010); Zink et al. (2017) }\end{array}$ \\
\hline soilN.mean & $\mathrm{g} \mathrm{kg}^{-1}$ & Mean top soil $\mathrm{N}$ in catchment & Ballabio et al. (2019) \\
\hline soilP.mean & $\mathrm{mg} \mathrm{kg}^{-1}$ & Mean top soil P in catchment & Ballabio et al. (2019) \\
\hline soilCN.mean & - & Mean top soil $\mathrm{C} / \mathrm{N}$ ratio in catchment & Ballabio et al. (2019) \\
\hline
\end{tabular}


https://doi.org/10.5194/essd-2022-6

Preprint. Discussion started: 1 March 2022

(c) Author(s) 2022. CC BY 4.0 License.

(c) (1)

\begin{tabular}{|c|c|c|c|c|}
\hline \multirow[t]{16}{*}{ Hydrology } & StartQobs & $\begin{array}{l}\text { YYYY- } \\
\text { MM-DD }\end{array}$ & $\begin{array}{l}\text { Starting date of Q time series used for calculating } \\
\text { hydrological indices (1999-11-01 or start of time } \\
\text { series) }\end{array}$ & \\
\hline & EndQobs & $\begin{array}{l}\text { YYYY- } \\
\text { MM-DD }\end{array}$ & $\begin{array}{l}\text { End date of Q time series used for calculating } \\
\text { hydrological indices }\end{array}$ & \\
\hline & meanQobs & $\mathrm{m}^{3} \mathrm{~s}^{-1}$ & $\begin{array}{l}\text { Mean discharge (period from StartQobs to } \\
\text { EndQobs) }\end{array}$ & $\begin{array}{l}\text { Musolff (2020); Musolff et al. } \\
\text { (2020) }\end{array}$ \\
\hline & medQobs & $\mathrm{m}^{3} \mathrm{~s}^{-1}$ & $\begin{array}{l}\text { Median discharge (period from StartQobs to } \\
\text { EndQobs) }\end{array}$ & $\begin{array}{l}\text { Musolff (2020); Musolff et al. } \\
\text { (2020) }\end{array}$ \\
\hline & specQobs & $\mathrm{mm} \mathrm{y}^{-1}$ & $\begin{array}{l}\text { Mean annual specific discharge (period from } \\
\text { StartQobs to EndQobs) }\end{array}$ & $\begin{array}{l}\text { Musolff (2020); Musolff et al. } \\
\text { (2020) }\end{array}$ \\
\hline & CVQobs & - & $\begin{array}{l}\text { Coefficient of variation of time series of daily Q } \\
\text { (period from StartQobs to EndQobs) }\end{array}$ & $\begin{array}{l}\text { Musolff (2020); Musolff et al. } \\
\text { (2020) }\end{array}$ \\
\hline & medSuQobs & $\mathrm{m}^{3} \mathrm{~s}^{-1}$ & $\begin{array}{l}\text { Median summer discharge (months May- } \\
\text { October) (period from StartQobs to EndQobs) }\end{array}$ & $\begin{array}{l}\text { Musolff (2020); Musolff et al. } \\
\text { (2020) }\end{array}$ \\
\hline & medWiQobs & $\mathrm{m}^{3} \mathrm{~s}^{-1}$ & $\begin{array}{l}\text { Median winter discharge (months November- } \\
\text { April) (period from StartQobs to EndQobs) }\end{array}$ & $\begin{array}{l}\text { Musolff (2020); Musolff et al. } \\
\text { (2020) }\end{array}$ \\
\hline & seasRQobs & - & $\begin{array}{l}\text { Seasonality index of Q, as ratio between median } \\
\text { summer and median winter Q (period from } \\
\text { StartQobs to EndQobs) }\end{array}$ & $\begin{array}{l}\text { Musolff (2020); Musolff et al. } \\
\text { (2020) }\end{array}$ \\
\hline & BFIQobs & - & $\begin{array}{l}\text { Base flow index calculated according to WMO } \\
\text { [2008] with lfstat package (version 0.9.4) in R } \\
\text { (period from StartQobs to EndQobs) }\end{array}$ & $\begin{array}{l}\text { Musolff (2020); Musolff et al. } \\
\text { (2020) }\end{array}$ \\
\hline & flashQobs & - & $\begin{array}{l}\text { Flashiness index of Q as the ratio between } 5 \% \\
\text { percentile and } 95 \% \text { percentile of Q time series } \\
\text { (period from StartQobs to EndQobs) }\end{array}$ & $\begin{array}{l}\text { Musolff (2020); Musolff et al. } \\
\text { (2020) }\end{array}$ \\
\hline & RCQobs & - & $\begin{array}{l}\text { Runoff coefficient (fraction of mean annual } \\
\text { precipitation discharging as specific discharge, } \\
\text { specQobs/P_mm) (period from StartQobs to } \\
\text { EndQobs) }\end{array}$ & $\begin{array}{l}\text { Musolff (2020); Musolff et al. } \\
\text { (2020) }\end{array}$ \\
\hline & Q_StartDate & $\begin{array}{l}\text { YYYY- } \\
\text { MM-DD }\end{array}$ & $\begin{array}{l}\text { Starting date of Q time series used for calculating } \\
\text { hydrological indices (from 1986, if possible and } \\
\text { at least } 3 \text { years of data, in few cases only earlier } \\
\text { data was available) }\end{array}$ & \\
\hline & Q_EndDate & $\begin{array}{l}\text { YYYY- } \\
\text { MM-DD }\end{array}$ & $\begin{array}{l}\text { End date of Q time series used for calculating } \\
\text { hydrological indices (as available) }\end{array}$ & \\
\hline & Q_mean & $\mathrm{m}^{3} \mathrm{~s}^{-1}$ & $\begin{array}{l}\text { Mean discharge (data for the period } \\
\text { Q_StartDate-Q_EndDate) }\end{array}$ & $\begin{array}{l}\text { Musolff (2020); Musolff et al. } \\
\text { (2020) }\end{array}$ \\
\hline & Q_median & $\mathrm{m}^{3} \mathrm{~s}^{-1}$ & $\begin{array}{l}\text { Median discharge (data for the period } \\
\text { Q_StartDate-Q_EndDate) }\end{array}$ & $\begin{array}{l}\text { Musolff (2020); Musolff et al. } \\
\text { (2020) }\end{array}$ \\
\hline
\end{tabular}




\begin{tabular}{|c|c|c|c|c|}
\hline & Q_spec & $\mathrm{mm} \mathrm{y}^{-1}$ & $\begin{array}{l}\text { Mean annual specific discharge (data for the } \\
\text { period Q_StartDate-Q_EndDate) }\end{array}$ & $\begin{array}{l}\text { Musolff (2020); Musolff et al. } \\
(2020)\end{array}$ \\
\hline & Q_CVQ & - & $\begin{array}{l}\text { Coefficient of variation of time series of daily Q } \\
\text { (data for the period Q_StartDate-Q_EndDate) }\end{array}$ & $\begin{array}{l}\text { Musolff (2020); Musolff et al. } \\
\text { (2020) }\end{array}$ \\
\hline & Q_medSum & $\mathrm{m}^{3} \mathrm{~s}^{-1}$ & $\begin{array}{l}\text { Median summer discharge (months May- } \\
\text { October) (data for the period Q_StartDate- } \\
\text { Q_EndDate) }\end{array}$ & $\begin{array}{l}\text { Musolff (2020); Musolff et al. } \\
\text { (2020) }\end{array}$ \\
\hline & Q_medWin & $\mathrm{m}^{3} \mathrm{~s}^{-1}$ & $\begin{array}{l}\text { Median winter discharge (months November- } \\
\text { April) (data for the period Q_StartDate- } \\
\text { Q_EndDate) }\end{array}$ & $\begin{array}{l}\text { Musolff (2020); Musolff et al. } \\
(2020)\end{array}$ \\
\hline & Q_Sum2Win & - & $\begin{array}{l}\text { Seasonality index of Q, as ratio between median } \\
\text { summer and median winter Q (data for the period } \\
\text { Q_StartDate-Q_EndDate) }\end{array}$ & $\begin{array}{l}\text { Musolff (2020); Musolff et al. } \\
\text { (2020) }\end{array}$ \\
\hline & BFI & - & $\begin{array}{l}\text { Base flow index calculated according to WMO } \\
\text { [2008] with lfstat package (version 0.9.4) in R } \\
\text { (data for the period Q_StartDate-Q_EndDate) }\end{array}$ & $\begin{array}{l}\text { Musolff (2020); Musolff et al. } \\
\text { (2020) }\end{array}$ \\
\hline & flashi & - & $\begin{array}{l}\text { Flashiness index of Q as the ratio between } 5 \% \\
\text { percentile and } 95 \% \text { percentile of Q time series } \\
\text { (data for the period Q_StartDate-Q_EndDate) }\end{array}$ & $\begin{array}{l}\text { Musolff (2020); Musolff et al. } \\
\text { (2020) }\end{array}$ \\
\hline Climate & P_mm & $\mathrm{mm} \mathrm{y}^{-1}$ & Mean annual precipitation (period 1986-2015) & Cornes et al. (2018) \\
\hline & P_SIsw & - & $\begin{array}{l}\text { Seasonality of precipitation as the ratio between } \\
\text { mean summer (Jun-Aug) and winter (Dec-Feb) } \\
\text { precipitation (period 1986-2015) }\end{array}$ & Cornes et al. (2018) \\
\hline & P_SI & - & $\begin{array}{l}\text { Seasonality index of precipitation as the mean } \\
\text { difference between monthly averages of daily } \\
\text { precipitation and year average of daily } \\
\text { precipitation (period 1986-2015) }\end{array}$ & Cornes et al. (2018) \\
\hline & P_lambda & $d^{-1}$ & $\begin{array}{l}\text { Mean precipitation frequency } \lambda \text { as used by Botter } \\
\text { et al. (2013) with rain days for precipitation } \\
\text { above } 1 \mathrm{~mm} \text { (period 1986-2015) }\end{array}$ & Cornes et al. (2018) \\
\hline & P_alpha & $\mathrm{mm} \mathrm{d}^{-1}$ & $\begin{array}{l}\text { Mean precipitation depth as used by Botter et al. } \\
\text { (2013) with rain days for precipitation above } \\
1 \mathrm{~mm} \text { (period 1986-2015) }\end{array}$ & \\
\hline & PET_mm & $\mathrm{mm} \mathrm{y}^{-1}$ & $\begin{array}{l}\text { Mean annual potential evapotranspiration } \\
\text { (period 1986-2015) }\end{array}$ & Cornes et al. (2018) \\
\hline & AI & - & $\begin{array}{l}\text { Aridity index as } \mathrm{AI}=\mathrm{PET} \text { _mm/P_mm (period } \\
\text { 1986-2015) }\end{array}$ & Cornes et al. (2018) \\
\hline & T_mean & ${ }^{\circ} \mathrm{C}$ & Mean annual air temperature (period 1986-2015) & Cornes et al. (2018) \\
\hline
\end{tabular}


Author contributions. PE carried out the study, processed and curated the data and created the figures and tables. PE, AM and RK conceptualized and designed the study following initial ideas and acquired funding from AM and SA. Several authors contributed to the data collection and processing: RK provided the gridded meteorological time series, simulated discharge data and atmospheric deposition data, MW provided time series of $\mathrm{N}$ surplus data for the catchments, OB collected the point source data for Germany. PE produced the original draft of the manuscript with contributions of AM and RK. All authors contributed to the reviewing and editing of the manuscript.

615 Competing interests. The authors declare that they have no conflict of interest.

Acknowledgements. We gratefully thank all data collectors, processors and providers including the federal state environmental agencies and all contributors to this data set. We especially thank Thomas Grau, Teresa Nitz, Joni Dehaspe, Stefanie Breese, Sophie Ehrhardt for their contributions for data 620 processing. We gratefully acknowledge Martin Bach and Uwe Häußermann, Justus-Liebig-University of Giessen, for the provision of the two data sets on the agricultural N surplus data for Germany. We acknowledge the E-OBS data set from the EU-FP6 project UERRA (http://www.uerra.eu) and the Copernicus Climate Change Service, and the data providers in the ECA\&D project (https://www.ecad.eu). The authors additionally acknowledge several organizations for the data products used here, including the 625 BfG, BGR, SGD, EEA, FAO, IIASA, ISRIC, ISSCAS, and JRC. The authors thank for the funding by the Deutsche Forschungsgemeinschaft - DFG (Dominant controls on catchment water quality dynamics - a Germany-wide analysis using data-driven models, DFG 392886738).

\section{References}

630 Addor, N., Newman, A. J., Mizukami, N., and Clark, M. P.: The CAMELS data set: catchment attributes and meteorology for large-sample studies, Hydrology and Earth System Sciences, 21, 5293-5313, https://doi.org/10.5194/hess-21-5293-2017, 2017.

Addor, N., Do, H. X., Alvarez-Garreton, C., Coxon, G., Fowler, K., and Mendoza, P. A.: Large-sample hydrology: recent progress, guidelines for new datasets and grand challenges, Hydrological Sciences Journal, 65, 712-725, https://doi.org/10.1080/02626667.2019.1683182, 2020. 
https://doi.org/10.5194/essd-2022-6

Preprint. Discussion started: 1 March 2022

(c) Author(s) 2022. CC BY 4.0 License.

Alvarez-Garreton, C., Mendoza, P. A., Boisier, J. P., Addor, N., Galleguillos, M., Zambrano-Bigiarini, M., Lara, A., Puelma, C., Cortes, G.,

635 Garreaud, R., McPhee, J., and Ayala, A.: The CAMELS-CL dataset: catchment attributes and meteorology for large sample studies - Chile dataset, Hydrology and Earth System Sciences, 22, 5817-5846, https://doi.org/10.5194/hess-22-5817-2018, 2018.

Bach, M. and Frede, H.-G.: Agricultural nitrogen, phosphorus and potassium balances in Germany —Methodology and trends 1970 to 1995 , Zeitschrift für Pflanzenernährung und Bodenkunde, 161, 385-393, https://doi.org/10.1002/jpln.1998.3581610406, 1998.

640 maps, Landscape and Urban Planning, 78, 289-299, https://doi.org/10.1016/j.landurbplan.2005.09.004, 2006.

Ballabio, C., Lugato, E., Fernández-Ugalde, O., Orgiazzi, A., Jones, A., Borrelli, P., Montanarella, L., and Panagos, P.: Mapping LUCAS topsoil chemical properties at European scale using Gaussian process regression, Geoderma, 355, 113912, https://doi.org/10.1016/j.geoderma.2019.113912, 2019.

Bartnicky, J. and Benedictow, A.: Atmospheric Deposition of Nitrogen to OSPAR Convention waters in the period 1995-2014, EMEP/MSC-

645 W Technical Report, 1/2007, Meteorological Synthesizing Centre-West (MSC-W), Norwegian Meteorological Institute, Oslo, 2017.

Bartnicky, J. and Fagerli, H.: Atmospheric Nitrogen in the OSPAR Convention Area in the Period 1990-2004. Summary Report for the OSPAR Convention., EMEP/MSC-W Technical Report, 4/2006, Meteorological Synthesizing Centre-West (MSC-W) of EMEP, Oslo, 2006. Basu, N. B., Destouni, G., Jawitz, J. W., Thompson, S. E., Loukinova, N. V., Darracq, A., Zanardo, S., Yaeger, M., Sivapalan, M., Rinaldo, A., and Rao, P. S. C.: Nutrient loads exported from managed catchments reveal emergent biogeochemical stationarity, Geophysical Research 650 Letters, 37, https://doi.org/10.1029/2010gl045168, 2010.

Behrendt, H., Huber, P., Opitz, D., Schmoll, O., Scholz, G., and Uebe, R.: Nutrient emissions into river basins of Germany, UBA-Texte, 23/00, 2000.

Behrendt, H., Bach, M., Kunkel, R., Opitz, D., Pagenkopf, W.-G., Scholz, G., and Wendland, F.: Nutrient Emissions into River Basins of Germany on the Basis of a Harmonized Procedure UBA-Texte, 82/03, 2003.

655 Beven, K. J. and Kirkby, M. J.: A physically based, variable contributing area model of basin hydrology / Un modèle à base physique de zone d'appel variable de l'hydrologie du bassin versant, Hydrological Sciences Bulletin, 24, 43-69, https://doi.org/10.1080/02626667909491834, 1979.

BGR: Bodenübersichtskarte der Bundesrepublik Deutschland 1:250.000 (BUEK250). Soil map of Germany 1:250,000, Federal Institute for Geosciences and Natural Resources (BGR) [dataset], 2018.

660 BGR \& UNESCO (eds.): International Hydrogeological Map of Europe 1 : 1,500,000 (IHME1500). Digital map data v1.1. [dataset], http://www.bgr.bund.de/ihme1500/, 2014.

BMU, Bundesministerium Für Umwelt, N. u. R. (Ed.): Hydrologischer Atlas von Deutschland, Datenquelle: Hydrologischer Atlas von Deutschland/BfG, 2000, Bonn/Berlin2000.

Botter, G., Basso, S., Rodriguez-Iturbe, I., and Rinaldo, A.: Resilience of river flow regimes, Proc Natl Acad Sci U S A, 110, 12925-12930, https://doi.org/10.1073/pnas.1311920110, 2013.

Büttner, O.: DE-WWTP - data collection of wastewater treatment plants of Germany (status 2015, metadata), HydroShare [dataset], https://doi.org/10.4211/hs.712c1df62aca4ef29688242eeab7940c, 2020.

Center for International Earth Science Information Network - CIESIN - Columbia University: Gridded Population of the World, Version 4 (GPWv4): Population Density, Revision 10, NASA Socioeconomic Data and Applications Center (SEDAC) [dataset],

670 https://doi.org/10.7927/H4DZ068D, 2017.

Chagas, V. B. P., Chaffe, P. L. B., Addor, N., Fan, F. M., Fleischmann, A. S., Paiva, R. C. D., and Siqueira, V. A.: CAMELS-BR: hydrometeorological time series and landscape attributes for 897 catchments in Brazil, Earth Syst. Sci. Data, 12, 2075-2096, https://doi.org/10.5194/essd-12-2075-2020, 2020.

Chen, D., Shen, H., Hu, M., Wang, J., Zhang, Y., and Dahlgren, R. A.: Chapter Five - Legacy Nutrient Dynamics at the Watershed Scale:

675 Principles, Modeling, and Implications, in: Advances in Agronomy, edited by: Sparks, D. L., Academic Press, 237-313, https://doi.org/10.1016/bs.agron.2018.01.005, 2018.

Cleveland, C. C., Townsend, A. R., Schimel, D. S., Fisher, H., Howarth, R. W., Hedin, L. O., Perakis, S. S., Latty, E. F., Von Fischer, J. C., Elseroad, A., and Wasson, M. F.: Global patterns of terrestrial biological nitrogen (N2) fixation in natural ecosystems, Global Biogeochemical Cycles, 13, 623-645, https://doi.org/10.1029/1999GB900014, 1999.

680 Cornes, R. C., van der Schrier, G., van den Besselaar, E. J. M., and Jones, P. D.: An Ensemble Version of the E-OBS Temperature and Precipitation Data Sets, Journal of Geophysical Research: Atmospheres, 123, 9391-9409, https://doi.org/10.1029/2017jd028200, 2018.

Coxon, G., Addor, N., Bloomfield, J. P., Freer, J., Fry, M., Hannaford, J., Howden, N. J. K., Lane, R., Lewis, M., Robinson, E. L., Wagener, T., and Woods, R.: CAMELS-GB: hydrometeorological time series and landscape attributes for 671 catchments in Great Britain, Earth Syst. Sci. Data, 12, 2459-2483, https://doi.org/10.5194/essd-12-2459-2020, 2020.

685 De Jager, A. and Vogt, J.: Rivers and Catchments of Europe - Catchment Characterisation Model (CCM) (2.1), European Commission, Joint Research Centre (JRC) [dataset], 2007.

Do, H. X., Westra, S., and Leonard, M.: A global-scale investigation of trends in annual maximum streamflow, Journal of Hydrology, 552, 28-43, https://doi.org/10.1016/j.jhydrol.2017.06.015, 2017. 
https://doi.org/10.5194/essd-2022-6

Preprint. Discussion started: 1 March 2022

(c) Author(s) 2022. CC BY 4.0 License.

Ebeling, P.: CCDB - catchment characteristics data base Germany, HydroShare [dataset],

690 https://doi.org/10.4211/hs.0fc1b5b1be4a475aacfd9545e72e6839, 2021.

Ebeling, P. and Dupas, R.: CCDB - catchment characteristics data base France and Germany, HydroShare [dataset], https://doi.org/10.4211/hs.c7d4df3ba74647f0aa83ae92be2e294b, 2021.

Ebeling, P., Kumar, R., and Musolff, A.: CCDB - catchment characteristics data base Germany, HydroShare [dataset], https://doi.org/10.4211/hs.82f8094dd61e449a826afdef820a2c19, 2021a.

695 Ebeling, P., Kumar, R., Weber, M., and Musolff, A.: QUADICA - water quality, discharge and catchment attributes for large-sample studies in Germany, HydroShare [dataset], https://doi.org/10.4211/hs.26e8238f0be14fa1a49641cd8a455e29, $2021 \mathrm{~b}$.

Ebeling, P., Kumar, R., Weber, M., Knoll, L., Fleckenstein, J. H., and Musolff, A.: Archetypes and Controls of Riverine Nutrient Export Across German Catchments, Water Resources Research, 57, e2020WR028134, https://doi.org/10.1029/2020WR028134, 2021c.

Ebeling, P., Dupas, R., Abbott, B., Kumar, R., Ehrhardt, S., Fleckenstein, J. H., and Musolff, A.: Long-Term Nitrate Trajectories Vary by

700 Season in Western European Catchments, Global Biogeochemical Cycles, 35, e2021GB007050, https://doi.org/10.1029/2021GB007050, 2021d.

EC: Council Directive 91/676/EEC of 12 December 1991 concerning the protection of waters against pollution caused by nitrates from agricultural sources, Official Journal of the European Communities, 1991a.

705 1991b.

EC: Directive 2000/60/EC of the European Parliament and of the Council of 23 October 2000 establishing a framework for Community action in the field of water policy, Official Journal of the European Communities, L 327, 1 - 73, 2000.

EEA: DEM over Europe from the GMES RDA project (EU-DEM, resolution 25m) - version 1, Oct. 2013, European Environmental Agency [dataset], 2013.

710 EEA: EU-Hydro River Network, European Environmental Agency. Copernicus Land Monitoring Service [dataset], 2016a.

EEA: CORINE Land Cover 2012 v18.5, European Environmental Agency [dataset], 2016b.

EEA: Waterbase - UWWTD: Urban Waste Water Treatment Directive - reported data (6) [dataset], 2017.

EEA: Waterbase - Water Quality ICM [dataset], 2020.

Ehrhardt, S., Ebeling, P., Dupas, R., Kumar, R., Fleckenstein, J. H., and Musolff, A.: Nitrate Transport and Retention in Western European

715 Catchments Are Shaped by Hydroclimate and Subsurface Properties, Water Resources Research, 57, e2020WR029469, https://doi.org/10.1029/2020WR029469, 2021.

FAO/IIASA/ISRIC/ISSCAS/JRC: Harmonized World Soil Database (version 1.2), FAO, Rome, Italy and IIASA, Laxenburg, Austria [dataset], 2012.

720 Fowler, K. J. A., Acharya, S. C., Addor, N., Chou, C., and Peel, M. C.: CAMELS-AUS: hydrometeorological time series and land

Gnann, S. J., Howden, N. J. K., and Woods, R. A.: Hydrological signatures describing the translation of climate seasonality into streamflow seasonality, Hydrol. Earth Syst. Sci., 24, 561-580, https://doi.org/10.5194/hess-24-561-2020, 2020.

Godsey, S. E., Hartmann, J., and Kirchner, J. W.: Catchment chemostasis revisited: Water quality responds differently to variations in weather and climate, Hydrological Processes, 33, 3056-3069, https://doi.org/10.1002/hyp.13554, 2019.

725 Godsey, S. E., Kirchner, J. W., and Clow, D. W.: Concentration-discharge relationships reflect chemostatic characteristics of US catchments, Hydrological Processes, 23, 1844-1864, https://doi.org/10.1002/hyp.7315, 2009.

Gupta, H. V., Perrin, C., Blöschl, G., Montanari, A., Kumar, R., Clark, M., and Andréassian, V.: Large-sample hydrology: a need to balance depth with breadth, Hydrol. Earth Syst. Sci., 18, 463-477, https://doi.org/10.5194/hess-18-463-2014, 2014.

730 hargreaves, G. H. and Samani, Z. A.: Referent//doi.org/10.13031/2013.26773, 1985.

Hartmann, J., Lauerwald, R., and Moosdorf, N.: A Brief Overview of the GLObal RIver Chemistry Database, GLORICH, Procedia Earth and Planetary Science, 10, 23-27, https://doi.org/10.1016/j.proeps.2014.08.005, 2014.

Häußermann, U., Bach, M., Klement, L., and Breuer, L.: Stickstoff-Flächenbilanzen für Deutschland mit Regionalgliederung Bundesländer und Kreise - Jahre 1995 bis 2017. Methodik, Ergebnisse und Minderungsmaßnahmen, Texte, 131/2019, 2019.

735 Hirsch, R. M. and De Cicco, L. A.: User Guide to Exploration and Graphics for RivEr Trends (EGRET) and dataRetrieval: R Packages for Hydrologic Data, U.S. Geological Survey Techniques and Methods book 4, chap. A10, 93, https://dx.doi.org/10.3133/tm4A10, 2015.

Hirsch, R. M., Moyer, D. L., and Archfield, S. A.: Weighted Regressions on Time, Discharge, and Season (WRTDS), with an Application to Chesapeake Bay River Inputs, JAWRA Journal of the American Water Resources Association, 46, 857-880, doi:10.1111/j.17521688.2010.00482.x, 2010.

740 Kaushal, S. S., Gold, A. J., Bernal, S., and Tank, J. L.: Diverse water quality responses to extreme climate events: an introduction, Biogeochemistry, 141, 273-279, https://doi.org/10.1007/s10533-018-0527-x, 2018.

Kingston, D. G., Massei, N., Dieppois, B., Hannah, D. M., Hartmann, A., Lavers, D. A., and Vidal, J. P.: Moving beyond the catchment scale: Value and opportunities in large-scale hydrology to understand our changing world, Hydrological Processes, https://doi.org/10.1002/hyp.13729, 2020. 
https://doi.org/10.5194/essd-2022-6

Preprint. Discussion started: 1 March 2022

(c) Author(s) 2022. CC BY 4.0 License.

745 Klingler, C., Schulz, K., and Herrnegger, M.: LamaH-CE: LArge-SaMple DAta for Hydrology and Environmental Sciences for Central Europe, Earth Syst. Sci. Data, 13, 4529-4565, https://doi.org/10.5194/essd-13-4529-2021, 2021.

Knoll, L., Breuer, L., and Bach, M.: Nation-wide estimation of groundwater redox conditions and nitrate concentrations through machine learning, Environmental Research Letters, 15, 064004, https://doi.org/10.1088/1748-9326/ab7d5c, 2020.

Kuentz, A., Arheimer, B., Hundecha, Y., and Wagener, T.: Understanding hydrologic variability across Europe through catchment classification, Hydrology and Earth System Sciences, 21, 2863-2879, https://doi.org/10.5194/hess-21-2863-2017, 2017.

Kumar, R., Samaniego, L., and Attinger, S.: Implications of distributed hydrologic model parameterization on water fluxes at multiple scales and locations, Water Resources Research, 49, 360-379, https://doi.org/10.1029/2012wr012195, 2013.

Li, L., Sullivan, P. L., Benettin, P., Cirpka, O. A., Bishop, K., Brantley, S. L., Knapp, J. L. A., van Meerveld, I., Rinaldo, A., Seibert, J., Wen, H., and Kirchner, J. W.: Toward catchment hydro-biogeochemical theories, WIREs Water, 8, e1495,

755 https://doi.org/10.1002/wat2.1495, 2021.

Livneh, B., Kumar, R., and Samaniego, L.: Influence of soil textural properties on hydrologic fluxes in the Mississippi river basin, Hydrological Processes, 29, 4638-4655, https://doi.org/10.1002/hyp.10601, 2015.

Merz, R., Tarasova, L., and Basso, S.: The flood cooking book: ingredients and regional flavors of floods across Germany, Environmental Research Letters, 15, 114024, https://doi.org/10.1088/1748-9326/abb9dd, 2020.

760 Monteith, D. T., Stoddard, J. L., Evans, C. D., de Wit, H. A., Forsius, M., Høgåsen, T., Wilander, A., Skjelkvåle, B. L., Jeffries, D. S., Vuorenmaa, J., Keller, B., Kopácek, J., and Vesely, J.: Dissolved organic carbon trends resulting from changes in atmospheric deposition chemistry, Nature, 450, 537-540, https://doi.org/10.1038/nature06316, 2007.

Murphy, R., Perry, E., Keisman, J., Harcum, J., and Leppo, E. W.: baytrends: Long Term Water Quality Trend Analysis. R package version 1.1.0, https://CRAN.R-project.org/package=baytrends, 2019.

765 Musolff, A.: WQQDB - water quality and quantity data base Germany: metadata, HydroShare [dataset], https://doi.org/10.4211/hs.a42addcbd59a466a9aa56472dfef8721, 2020.

Musolff, A., Fleckenstein, J. H., Opitz, M., Büttner, O., Kumar, R., and Tittel, J.: Spatio-temporal controls of dissolved organic carbon stream water concentrations, Journal of Hydrology, 566, 205-215, https://doi.org/10.1016/j.jhydrol.2018.09.011, 2018.

770 Germany [dataset], 2020.

Newman, A. J., Clark, M. P., Sampson, K., Wood, A., Hay, L. E., Bock, A., Viger, R. J., Blodgett, D., Brekke, L., Arnold, J. R., Hopson, T., and Duan, Q.: Development of a large-sample watershed-scale hydrometeorological data set for the contiguous USA: data set characteristics and assessment of regional variability in hydrologic model performance, Hydrol. Earth Syst. Sci., 19, 209-223, https://doi.org/10.5194/hess-19-209-2015, 2015.

775 Pflugmacher, D., Rabe, A., Peters, M., and Hostert, P.: Pan-European land cover map of 2015 based on Landsat and LUCAS data, PANGAEA [dataset], https://doi.org/10.1594/PANGAEA.896282, 2018.

Rotteveel, L. and Sterling, S. M.: The Surface Water Chemistry (SWatCh) database: A standardized global database of water chemistry to facilitate large-sample hydrological research, Earth Syst. Sci. Data Discuss., 2021, 1-17, https://doi.org/10.5194/essd-2021-43, 2021.

Samaniego, L., Kumar, R., and Attinger, S.: Multiscale parameter regionalization of a grid-based hydrologic model at the mesoscale, Water

780 Resources Research, 46, https://doi.org/10.1029/2008WR007327, 2010.

Schmidt, L., Heße, F., Attinger, S., and Kumar, R.: Challenges in applying machine learning models for hydrological inference: A case study for flooding events across Germany, Water Resources Research, n/a, e2019WR025924, https://doi.org/10.1029/2019wr025924, 2020.

Shen, C.: A Transdisciplinary Review of Deep Learning Research and Its Relevance for Water Resources Scientists, Water Resources Research, 54, 8558-8593, https://doi.org/10.1029/2018wr022643, 2018.

785 Simpson, D., Benedictow, A., Berge, H., Bergström, R., Emberson, L. D., Fagerli, H., Flechard, C. R., Hayman, G. D., Gauss, M., Jonson, J. E., Jenkin, M. E., Nyíri, A., Richter, C., Semeena, V. S., Tsyro, S., Tuovinen, J. P., Valdebenito, Á., and Wind, P.: The EMEP MSC-W chemical transport model - technical description, Atmos. Chem. Phys., 12, 7825-7865, https://doi.org/10.5194/acp-12-7825-2012, 2012.

Sivapalan, M.: Pattern, Process and Function: Elements of a Unified Theory of Hydrology at the Catchment Scale, in: Encyclopedia of Hydrological Sciences, edited by: Anderson, M. G., and McDonnell, J. J., https://doi.org/10.1002/0470848944.hsa012, 2006.

790 Tarasova, L., Basso, S., Wendi, D., Viglione, A., Kumar, R., and Merz, R.: A Process-Based Framework to Characterize and Classify Runoff Events: The Event Typology of Germany, Water Resources Research, 56, e2019WR026951, https://doi.org/10.1029/2019WR026951, 2020. Twarakavi, N. K. C., Sakai, M., and Šimůnek, J.: An objective analysis of the dynamic nature of field capacity, Water Resources Research, 45, https://doi.org/10.1029/2009WR007944, 2009.

UNEP: GEMStat database of the Global Environment Monitoring System for Freshwater (GEMS/Water) Programme., United Nations

795 Environment Programme [dataset], 2018.

van Genuchten, M. T.: A Closed-form Equation for Predicting the Hydraulic Conductivity of Unsaturated Soils, Soil Science Society of America Journal, 44, 892-898, https://doi.org/10.2136/sssaj1980.03615995004400050002x, 1980.

Vigiak, O., Grizzetti, B., Zanni, M., Aloe, A., Dorati, C., Bouraoui, F., and Pistocchi, A.: Domestic waste emissions to European freshwaters in the 2010s (v. 1.0), European Commission, Joint Research Centre (JRC) [Dataset] [dataset], 2019. 
https://doi.org/10.5194/essd-2022-6

Preprint. Discussion started: 1 March 2022

(c) Author(s) 2022. CC BY 4.0 License.

(c) (1)

800 Vigiak, O., Grizzetti, B., Zanni, M., Aloe, A., Dorati, C., Bouraoui, F., and Pistocchi, A.: Domestic waste emissions to European waters in the 2010s, Scientific Data, 7, 33, https://doi.org/10.1038/s41597-020-0367-0, 2020.

Virro, H., Amatulli, G., Kmoch, A., Shen, L., and Uuemaa, E.: GRQA: Global River Water Quality Archive, Earth Syst. Sci. Data Discuss., 2021, 1-30, https://doi.org/10.5194/essd-2021-51, 2021.

WMO: Manual on Low-flow Estimation and Prediction, World Meteorological Organization, 2008.

805 Wollheim, W. M., Bernal, S., Burns, D. A., Czuba, J. A., Driscoll, C. T., Hansen, A. T., Hensley, R. T., Hosen, J. D., Inamdar, S., Kaushal, S. S., Koenig, L. E., Lu, Y. H., Marzadri, A., Raymond, P. A., Scott, D., Stewart, R. J., Vidon, P. G., and Wohl, E.: River network saturation concept: factors influencing the balance of biogeochemical supply and demand of river networks, Biogeochemistry, 141, 503-521, https://doi.org/10.1007/s10533-018-0488-0, 2018.

810 Yang, S., Bertuzzo, E., Büttner, O., Borchardt, D., and Rao, P. S. C.: Emergent spatial patterns of competing benthic and pelagic algae in a river network: A parsimonious basin-scale modeling analysis, Water Research, 193, 116887, https://doi.org/10.1016/j.watres.2021.116887, 2021.

Zacharias, S. and Wessolek, G.: Excluding Organic Matter Content from Pedotransfer Predictors of Soil Water Retention, Soil Science Society of America Journal, 71, 43-50, https://doi.org/10.2136/sssaj2006.0098, 2007.

Zarnetske, J. P., Bouda, M., Abbott, B. W., Saiers, J., and Raymond, P. A.: Generality of Hydrologic Transport Limitation of Watershed

815 Organic Carbon Flux Across Ecoregions of the United States, Geophysical Research Letters, 45, 11,702-711,711, https://doi.org/10.1029/2018gl080005, 2018.

Zink, M., Kumar, R., Cuntz, M., and Samaniego, L.: A high-resolution dataset of water fluxes and states for Germany accounting for parametric uncertainty, Hydrology and Earth System Sciences, 21, 1769-1790, https://doi.org/10.5194/hess-21-1769-2017, 2017. 